\title{
Orally Active Peptide Vector Allows Using Cannabis to Fight Pain While Avoiding Side Effects
}

\author{
Maria Gallo, Estefanía Moreno, Sira Defaus, Antonio Ortega-Alvaro, Angel Gonzalez, Patricia Robledo, \\ Marco Cavaco, Vera Neves, Miguel A. R. B. Castanho, Vicent Casadó, Leonardo Pardo, \\ Rafael Maldonado,* and David Andreu*
}

Cite This: J. Med. Chem. 2021, 64, 6937-6948

Read Online

ACCESS | Llll Metrics \& More | 国 Article Recommendations | St Supporting Information

ABSTRACT: The activation of cannabinoid $\mathrm{CB}_{1}$ receptors $\left(\mathrm{CB}_{1} \mathrm{R}\right)$ by $\Delta^{9}$-tetrahydrocannabinol (THC), the main component of Cannabis sativa, induces analgesia. $\mathrm{CB}_{1} \mathrm{R}$ activation, however, also causes cognitive impairment via the serotonin $5 \mathrm{HT}_{2 \mathrm{~A}}$ receptor $\left(5 \mathrm{HT}_{2 \mathrm{~A}} \mathrm{R}\right)$, a component of a $\mathrm{CB}_{1} \mathrm{R}-5 \mathrm{HT}_{2 \mathrm{~A}} \mathrm{R}$ heteromer, posing a serious drawback for cannabinoid therapeutic use. We have shown that peptides reproducing $\mathrm{CB}_{1} \mathrm{R}$ transmembrane (TM) helices 5 and 6 , fused to a cell-penetrating sequence (CPP), can alter the structure of the $\mathrm{CB}_{1} \mathrm{R}-5 \mathrm{HT}_{2 \mathrm{~A}} \mathrm{R}$ heteromer and avert $\mathrm{THC}$ cognitive impairment while preserving analgesia. Here, we report the optimization of these prototypes into drug-like leads by (i) shortening the TM5, TM6, and CPP sequences, without losing the

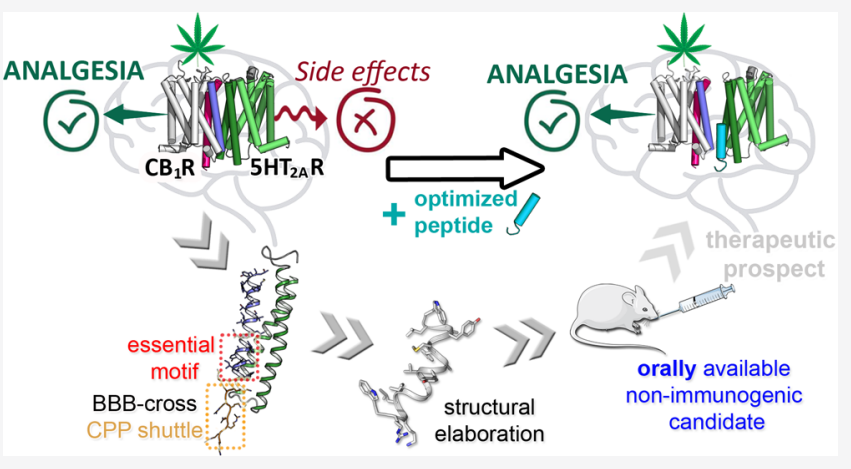
ability to disturb the $\mathrm{CB}_{1} \mathrm{R}-5 \mathrm{HT}_{2 \mathrm{~A}} \mathrm{R}$ heteromer, and (ii) extensive sequence remodeling to achieve protease resistance and blood-brain barrier penetration. Our efforts have culminated in the identification of an ideal candidate for cannabis-based pain management, an orally active 16-residue peptide preserving THCinduced analgesia.

\section{INTRODUCTION}

About $20 \%$ of the population suffers from chronic pain that seriously affects personal and professional life, highlighting the urgent need for analgesics that effectively alleviate pain with minimal side effects. ${ }^{1}$ Opioids, thus far the mainstay in severe pain management, are under intense debate for their poor safety profiles and high potential for abuse, as reflected in the opioid abuse disorder epidemic claiming about 145 deaths/day in the recent years in the USA. ${ }^{2,3}$ On the other hand, patients with minor pain manifestations are usually dealt with nonsteroidal anti-inflammatories (NSAIDs) that not only fail quite often to achieve adequate relief but also have serious side effects (e.g., gastrointestinal and renal). ${ }^{4}$ Thus, there is a need to fill the therapeutic gap between opioids and NSAIDs under multiple moderate pain conditions or in situations where opioids are ineffective, such as severe neuropathic pain. ${ }^{5}$

The analgesic potential of cannabinoid compounds has long been recognized. ${ }^{6-8}$ The activation of cannabinoid $\mathrm{CB}_{1}$ receptors $\left(\mathrm{CB}_{1} \mathrm{R}\right)$ by agonists, such as $\Delta^{9}$-tetrahydrocannabinol (THC), the main psychoactive component of Cannabis sativa, elicits therapeutically relevant responses for the treatment of migraine, ${ }^{9,10}$ rheumatoid arthritis, ${ }^{10}$ osteoarthritis, ${ }^{11}$ neuropathic, ${ }^{12}$ or cancer-related pain, ${ }^{13}$ among many others. Unfortunately, $\mathrm{CB}_{1} \mathrm{R}$ activation is also linked to side effects, such as memory impairment, with major consequences in cannabis users. ${ }^{8,14-17}$ These adverse effects pose a serious hurdle to the therapeutic use of cannabinoids; hence, the possibility to minimize their impact would constitute a major breakthrough.

Behavioral studies in mice lacking the serotonin $5 \mathrm{HT}_{2 \mathrm{~A}}$ receptor $\left(5 \mathrm{HT}_{2 \mathrm{~A}} \mathrm{R}\right)$ revealed a remarkable dissociation between the beneficial antinociceptive effects of THC and its detrimental amnesic properties. ${ }^{18}$ As $\mathrm{CB}_{1} \mathrm{R}$ and $5 \mathrm{HT}_{2 \mathrm{~A}} \mathrm{R}$ are $\mathrm{G}$ protein-coupled receptors (GPCRs), a class of proteins frequently forming oligomers in cells, ${ }^{19}$ we provided evidence that the underlying molecular basis for that observation was the formation of $\mathrm{CB}_{1} \mathrm{R}-5 \mathrm{HT}_{2 \mathrm{~A}} \mathrm{R}$ heteromers. ${ }^{18}$ Both receptors are functionally active in specific brain regions; the heteromer shows specific biochemical signatures distinct from those of the protomers, in artificial cell lines as well as native tissues; very importantly, while the cognitive impairment caused by THC is due to the $C_{1} \mathrm{R}-5 \mathrm{HT}_{2 \mathrm{~A}} \mathrm{R}$ heteromer, the antinociceptive effects result solely from $\mathrm{CB}_{1} \mathrm{R}$ activation. ${ }^{18}$ The arrangement

Received: March 17, 2021

Published: April 23, 2021 
Table 1. From TM5/6 Prototypes to a Drug-Like Finalist Peptide ${ }^{a}$

\begin{tabular}{|c|c|c|c|}
\hline \multicolumn{2}{|c|}{ peptide } & \multirow{2}{*}{$\frac{\text { sequence }^{b}}{\text { ETYLMFWIGVTSVLLLFIVYAYMYILWGRKKRRQRRR }^{\text {. }}}$} & \multirow{2}{*}{$\frac{\text { residues }}{37}$} \\
\hline prototypes $^{18}$ & TM5-Tat & & \\
\hline & Tat-TM6 & GRKKRRQRRRKTLVLILVVLIICWGPLLAIMVYDVF & 36 \\
\hline optimized ca & & wliymyayvaGilkrw & 16 \\
\hline
\end{tabular}

${ }^{a}$ A detailed list of all peptides used in the various rounds of the optimization process is given in Tables S1-S4. ${ }^{b}$ Upper and lower case denote Land D-residues, respectively.

of $\mathrm{CB}_{1} \mathrm{R}$ and $5 \mathrm{HT}_{2 \mathrm{~A}} \mathrm{R}$ protomers in the heteromer is via transmembrane (TM) helices 5 and $6^{18}$ as studied by bimolecular fluorescence complementation (BiFC) experiments with synthetic peptides TM5-Tat and Tat-TM6, where TM5 and 6 helices are fused to cell-penetrating peptide (CPP) GRKKRRQRRR, that is, HIV Tat $(48-57),{ }^{20}$ respectively, at $\mathrm{N}$ - or $\mathrm{C}$-termini, ensuring TM native alignment relative to the membrane.

The formation of a stable four-helix bundle between these TM5 and 6 helices of both protomers, as described for the dimeric crystal of the $\mu$-opioid receptor, ${ }^{21}$ was suggested to be involved in the allosteric interactions between protomers and in the mechanisms behind the specific signaling signatures of the heteromer. ${ }^{18,22}$ Moreover, interfering TM5-Tat and TatTM6 peptides were able to alter the structure of the heteromer in vivo, leading to a selective abrogation of memory impairments caused by the exposure to THC. ${ }^{18}$ From this, it was logical to assume that disturbing the formation of the $\mathrm{CB}_{1} \mathrm{R}-5 \mathrm{HT}_{2 \mathrm{~A}} \mathrm{R}$ heteromer might be an effective strategy for harnessing the therapeutic potential of THC while avoiding its side effects. TM5-Tat and Tat-TM6 peptides, however, were ungainly therapeutic leads with poor prospects related to their large size, low solubility, and inability to cross the blood-brain barrier (BBB). We now report on a comprehensive optimization effort leading from those prototypes to a candidate with vastly improved, drug-like features (Table 1) including small size, proteolytic stability, BBB crossing ability, and, remarkably, oral activity, thereby achieving the desired effects, both in vitro and in vivo.

\section{RESULTS}

Shorter Peptides Mimicking $\mathrm{CB}_{1} \mathrm{R}$ TM Helices 5 and 6 and Altering $C_{1} R-5 H_{2 A} R$ Heteromers. The design of these peptides required the identification of the amino acid residues in TM5-Tat and Tat-TM6 that contribute more significantly to the binding to $5 \mathrm{HT}_{2 \mathrm{~A}} \mathrm{R}$. This was studied by several replicas of unbiased $1 \mu \mathrm{s}$ molecular dynamic (MD) simulations of TM5-Tat and Tat-TM6 in complex with $5 \mathrm{HT}_{2 \mathrm{~A}} \mathrm{R}$ (see Figure $1 \mathrm{a}-\mathrm{c}$ and Experimental Section). The simulations show that the intracellular part of the peptides remains more stable than the extracellular one (more noticeable for Tat-TM6) due to specific interactions with $5 \mathrm{HT}_{2 \mathrm{~A}} \mathrm{R}$ (mainly the V19-Y20-Y22-M23-L26-W27 stretch in TM5-Tat or the K11-V14-L17-V18 stretch in Tat-TM6, Figure 1d,e).

Based on these predictions, ${ }^{18}$ peptides VYAYMYILW-Tat and Tat-KTLVLILVV (1 and $\mathbf{3}$, Table S1), respectively, mimicking the key interactions of TM5-Tat and Tat-TM6, were designed. Their ability to alter $\mathrm{CB}_{1} \mathrm{R}-5 \mathrm{HT}_{2 \mathrm{~A}} \mathrm{R}$ heteromer formation was first tested by BiFC assays, ${ }^{18,23,24}$ in HEK-293T cells transfected with receptors fused to two complementary halves of YFP $\left(5 \mathrm{HT}_{2 \mathrm{~A}} \mathrm{R}\right.$-cYFP and $\left.\mathrm{CB}_{1} \mathrm{R}-\mathrm{nYFP}\right)$. In this assay, 1 and 3 caused a decrease in fluorescence complementation comparable to the TM5-Tat and Tat-TM6 prototypes, in contrast to peptide TM7-Tat, used as a negative control (Figure 2a). Moreover, the biochemical properties of the heteromer differ from those of the protomers. ${ }^{18,23,24}$ In $\mathrm{CB}_{1} \mathrm{R}-$ $5 \mathrm{HT}_{2 \mathrm{~A}} \mathrm{R}$, in addition to a $\mathrm{G}_{\mathrm{q}}$ to $\mathrm{G}_{\mathrm{i}}$ switch in $5 \mathrm{HT}_{2 \mathrm{~A}} \mathrm{R}$ coupling preference, antagonist binding to one of the receptors blocks signaling of the interacting receptor (known as crossantagonism), and costimulation with both agonists does not produce an additive effect (known as negative cross-talk). ${ }^{23,24}$ Thus, we next determined signaling after receptor activation by measuring cAMP levels [decrease in forskolin (FK)-induced cAMP as the result of adenylate cyclase inhibition by $\mathrm{G}_{\mathrm{i}}$ ] or the increase in $\mathrm{pERK}$ in the ERK1/2 phosphorylation pathway (Figure $2 \mathrm{~d}, \mathrm{~g}$ ). Cells stimulated with FK and treated with the $\mathrm{CB}_{1} \mathrm{R}$ agonist WIN 55,212-2 (WIN) or $5 \mathrm{HT}_{2 \mathrm{~A}} \mathrm{R}$ agonist 2,5dimethoxy-4-iodoamphetamine (DOI) showed reduced cAMP production in all groups, as expected for $\mathrm{G}_{\mathrm{i}}$-coupled receptors. Neither TM5-Tat, Tat-TM6, peptides 1 or 3, nor TM7-Tat (negative control) influenced $\mathrm{G}$ protein coupling preferences $\left(5 \mathrm{HT}_{2 \mathrm{~A}} \mathrm{R}\right.$ remains $\mathrm{G}_{\mathrm{i}}$-coupled in the presence of interfering peptides). The $\mathrm{CB}_{1} \mathrm{R}$ antagonist rimonabant (RIM) blocked the decrease in FK-induced cAMP or the increase in pERK triggered by the $5 \mathrm{HT}_{2 \mathrm{~A}} \mathrm{R}$ agonist DOI, and the $5 \mathrm{HT}_{2 \mathrm{~A}} \mathrm{R}$ antagonist MDL 100,907 (MDL) also blocked the decrease in cAMP and increase in pERK induced by the $\mathrm{CB}_{1} \mathrm{R}$ agonist WIN (bidirectional cross-antagonism). Notably, peptides 1 and 3 eliminated this bidirectional cross-antagonism as efficiently as TM5-Tat and Tat-TM6 peptides, an effect that was not observed with TM7-Tat (negative control). Coadministration of WIN and DOI agonists, in the absence of peptides, does not lead to a further statistically significant decrease in cAMP or increase in pERK (negative cross-talk). However, in the presence of $\mathbf{1}$ and 3, as well as TM5-Tat and Tat-TM6 (but not TM7-Tat), the simultaneous addition of both agonists results in a significant decrease in cAMP or an increase in pERK (absence of negative cross-talk). In sum, interfering peptides $\mathbf{1}$ and 3 successfully blocked key biochemical signatures (cross-antagonism and negative crosstalk) of the $\mathrm{CB}_{1} \mathrm{R}-5 \mathrm{HT}_{2 \mathrm{~A}} \mathrm{R}$ heteromer as efficiently as TM5Tat and Tat-TM6.

We assumed that the segments of peptides TM5-Tat and Tat-TM6 replicating $\mathrm{CB}_{1} \mathrm{R}$ TM helices 5 and 6 are membraneembedded as in the receptor, whereas Tat $(48-57)$ is in the intracellular space (Figure 1b,c). Peptides 2 and 4 (Table S1), lacking the Tat $(48-57)$ sequence, had no effect on decreasing fluorescence complementation (Figure 2a) or in signaling (Figure $2 \mathrm{~d}-\mathrm{g}$ ), underscoring the essential role of the CPP motif.

HIV-Tat Replacement by Shorter CPPs. Inspired by recent studies, ${ }^{25-28}$ a second set of analogues were devised (Table S2) in which four alternatives to 10-residue Tat(4857) were explored: (i) 7-residue $\mathrm{PepH} 3$ (AGILKRW), a reported $\mathrm{BBB}$ shuttle ${ }^{25}$ (peptides 5 and 9); (ii) 6-residue SKSKSK $^{26}$ (6 and 10); (iii) 5-residue $\operatorname{RLRWR}^{27}$ (7 and 11), and (iv) 3-residue $\mathrm{RKR}^{28}$ (8 and 12). The last two CPP motifs 

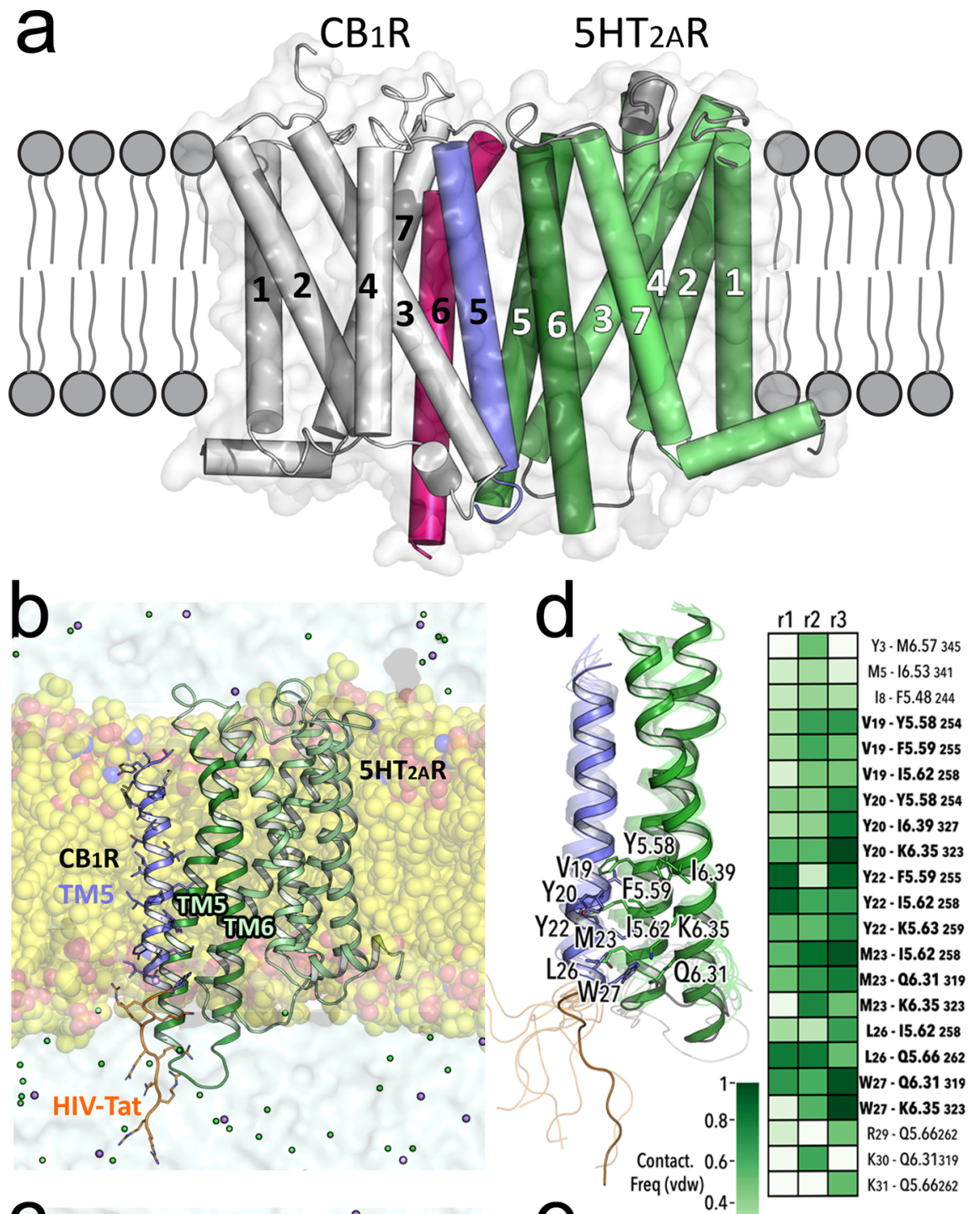

$\mathrm{Y}_{20} \cdot 16.39327$
$\mathrm{Y}_{20} \cdot \mathrm{K} 6.35323$

Y $\quad Y_{22} \cdot F 5.59255$

$Y_{22}-15.62258$

$Y_{22} \cdot K 5.63259$ M23 - 15.62258 M23 - 06.31319 M23 - K6.35 323 M23 - K6.35 323
L26 - 15.62258 L26. 05.66262 W27 -06.31319

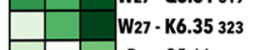
\begin{tabular}{|l|l|l|l|l}
\hline & & & $R 29 \cdot 05.66262$ \\
\hline & & & \\
$K$ & 0 & 06.31319
\end{tabular}
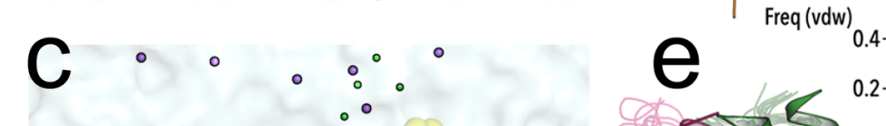

K31-05.66262
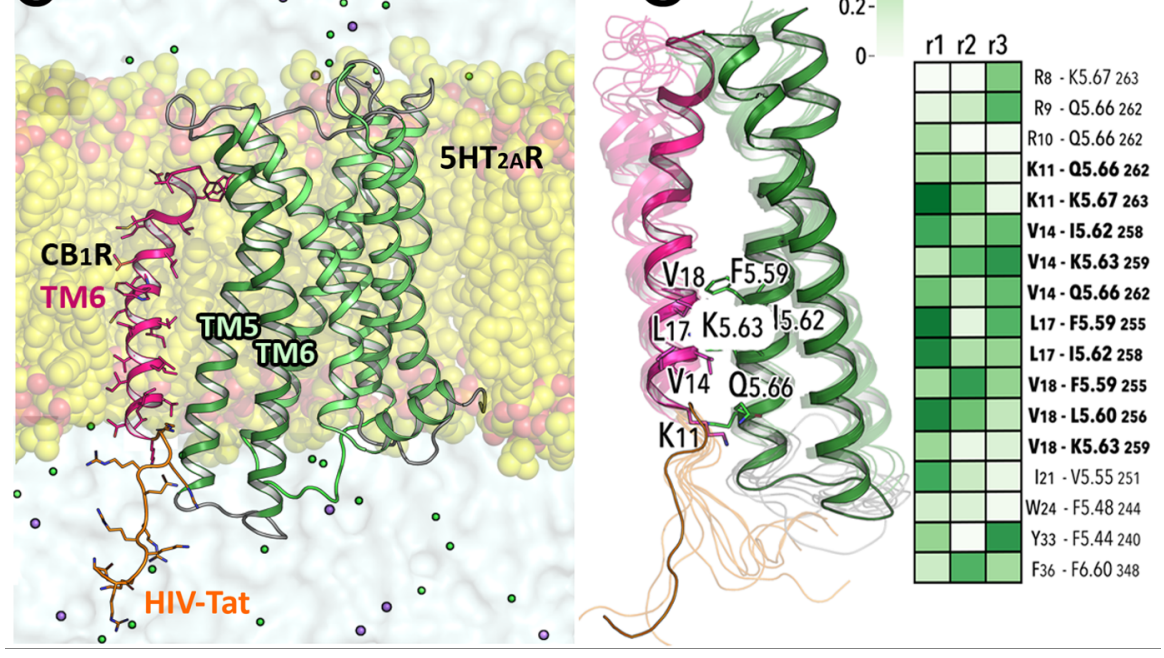

Figure 1. $(\mathrm{a}-\mathrm{e}) \mathrm{MD}$ simulations of $5 \mathrm{HT}_{2 \mathrm{~A}} \mathrm{R}$ in complex with TM5-Tat and Tat-TM6 peptides. The previously published computational model of the $\mathrm{CB}_{1} \mathrm{R}-5 \mathrm{HT}_{2 \mathrm{~A}} \mathrm{R}$ heteromer ${ }^{18,20}$ (panel a) was used as the starting point for MD simulations (see Experimental Section) of a membraneembedded (yellow spheres) $5 \mathrm{HT}_{2 \mathrm{~A}} \mathrm{R}$ (green ribbons) in complex with peptides where the TM5 (blue ribbon, panel b) or TM6 (red ribbon, panel c) sequences are fused to HIV-Tat(48-57) (orange). These TM5-Tat and Tat-TM6 peptides (Table 1) were stable in the three replicas of $1 \mu$ s unbiased MD, as shown by root-mean-square deviations (Figure S1). Panels (d,e) show detailed views of the interactions between TM5-Tat and Tat-TM6, respectively, with TM helices 5 and 6 of $5 \mathrm{HT}_{2 \mathrm{~A}} \mathrm{R}$. Snapshots along the trajectories are shown as transparent ribbons, whereas representative structures are solid ribbons. Side chain residues involved in stable interactions of TM5-Tat and Tat-TM6 with 5HT ${ }_{2 \mathrm{~A}} \mathrm{R}$ 
Figure 1. continued

(Ballesteros-Weinstein notation) during the MD simulations are labeled. Interaction frequency maps for frequencies above $50 \%$ in at least one of the three replicas ( $11, \mathrm{r} 2$, and $\mathrm{r} 3$ ) are depicted. TM5-Tat and Tat-TM6 residues involved in stable interactions with two or more $5 \mathrm{HT}_{2 \mathrm{~A}} \mathrm{R}$ residues are highlighted in bold.

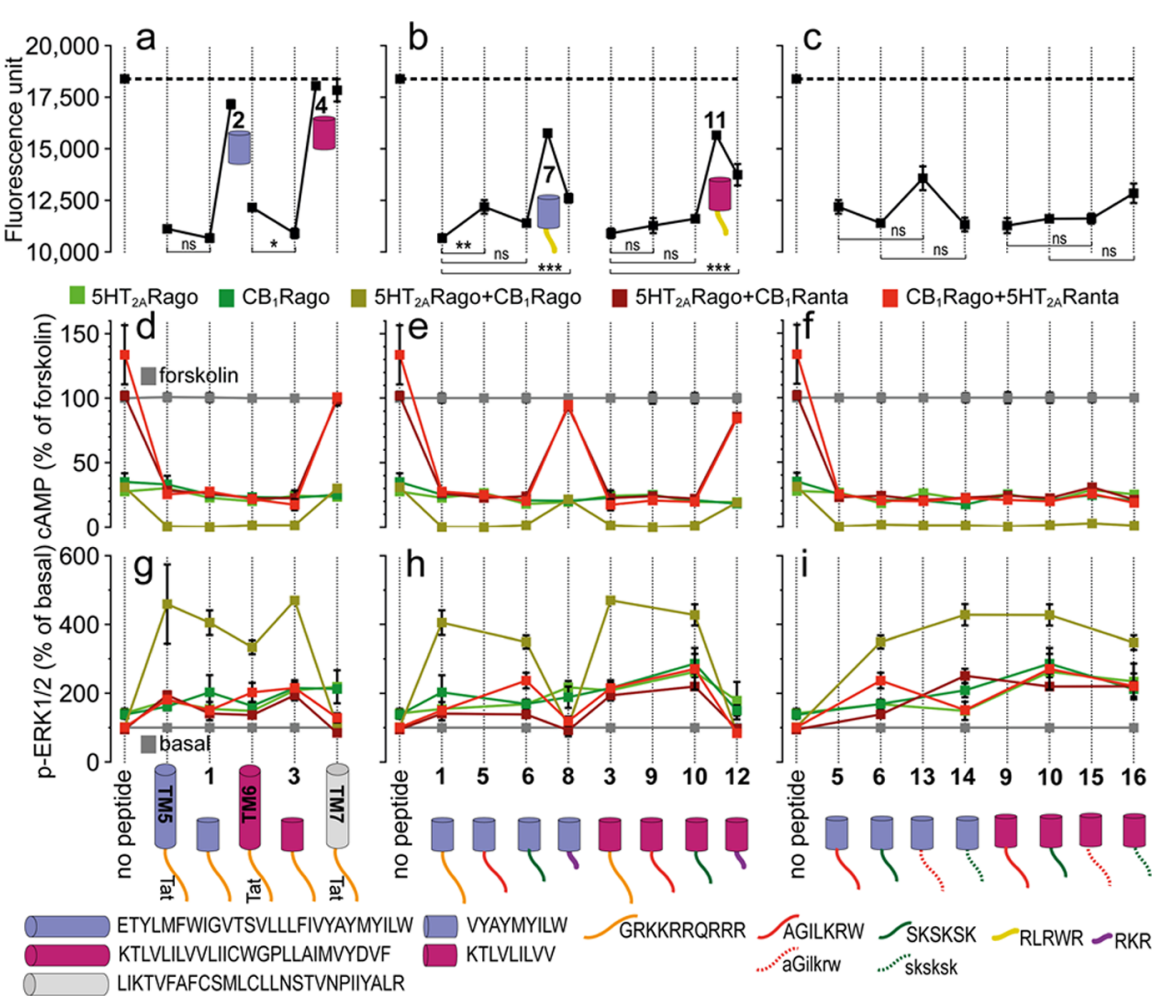

Figure 2. $(\mathrm{a}-\mathrm{c}) \mathrm{BiFC}$ analysis of the effect of designed peptides on $\mathrm{CB}_{1} \mathrm{R}-5 \mathrm{HT}_{2 \mathrm{~A}} \mathrm{R}$ heteromerization. Fluorescence $(530 \mathrm{~nm})$ of $\mathrm{HEK}-293 \mathrm{~T}$ cells transfected with $5 \mathrm{HT}_{2 \mathrm{~A}} \mathrm{R}$-cYFP and $\mathrm{CB}_{1} \mathrm{R}$-nYFP treated with a vehicle (no peptide) or $4 \mu \mathrm{M}$ peptide for $4 \mathrm{~h}$. Values are mean $\pm \mathrm{SEM}$ of $n=10-$ 30; TM5-Tat and Tat-TM6 are positive controls, whereas TM7-Tat is a negative control; ns (no significant), $*(p<0.05), * *(p<0.01)$, and $* * *(p$ $<0.001$ ) represent significantly different (two-tailed) values (one-way ANOVA followed by Tukey's multiple comparison tests). (d-i) Effect of designed peptides on the decrease in FK-induced cAMP $(\mathrm{d}-\mathrm{f})$ or increase in ERK1/2 phosphorylation. ( $\mathrm{g}-\mathrm{i}$ ) Transfected cells preincubated with a vehicle (no peptide) or with $5 \mathrm{HT}_{2 \mathrm{~A}} \mathrm{R}\left(5 \mathrm{HT}_{2 \mathrm{~A}} \mathrm{Rago}\right.$, DOI, $\left.100 \mathrm{nM}\right)$ or $\mathrm{CB}_{1} \mathrm{R}\left(\mathrm{CB}_{1} \mathrm{Rago}\right.$, WIN, $\left.100 \mathrm{nM}\right)$ agonists or with $5 \mathrm{HT}_{2 \mathrm{~A}} \mathrm{R}\left(5 \mathrm{HT} \mathrm{T}_{2 \mathrm{~A}} \mathrm{Ranta}\right.$, $\mathrm{MDL}, 300 \mathrm{nM})$ or $\mathrm{CB}_{1} \mathrm{R}\left(\mathrm{CB}_{1}\right.$ Ranta, RIM, $\left.1 \mu \mathrm{M}\right)$ antagonists and combinations thereof, in the presence or absence of $0.5 \mu \mathrm{M}$ FK. Values in panels $(\mathrm{d}-\mathrm{f})$ are mean \pm SEM of $n=3-6$ of FK-treated cells. Quantification of phosphorylated ERK-1/2 was determined by the $\alpha$-screen bead-based technology. Values in panels $(\mathrm{g}-\mathrm{i})$, expressed as a percentage of basal (nontreated cells), are mean \pm SEM of $n=4-9$. Two-way ANOVA followed by Tukey's multiple comparison tests was used to analyze the data (Table S5). Cartoons depict the designed peptides (cylinders with color codes as in Figure 1) fused to different CPPs (lines).

(7, 8, 11, and 12) were not as efficient as Tat(48-57) in decreasing fluorescence complementation, as measured in BiFC assays (Figure $2 \mathrm{~b}$ ), neither could $\mathbf{8}$ or $\mathbf{1 2}$ abolish the cross-antagonism and negative cross-talk signatures of the $\mathrm{CB}_{1} \mathrm{R}-5 \mathrm{HT}_{2 \mathrm{~A}} \mathrm{R}$ heteromer (Figure $2 \mathrm{e}, \mathrm{h}$ ). In contrast, peptides $5 / 9$ and $6 / 10$ were as effective as peptides $1 / 3$ in fluorescence complementation or signaling (Figure $2 \mathrm{~b}, \mathrm{e}, \mathrm{h}$ ) and were thus selected for further optimization.

CPP Stereochemistry and Its Significance. Replacement of natural L-by D-amino acids results in CPP sequences with improved cell entry and metabolic stability. ${ }^{29,30}$ We thus switched the CPP motifs of peptides 5, 6, 9, and 10 to their enantiomeric $\mathrm{D}$-versions, while preserving the $\mathrm{L}$ configuration for the cell membrane-embedded sections replicating $\mathrm{CB}_{1} \mathrm{R}$ TM5 or 6 (peptides 13-16, Table S3). Trypsin incubation over $24 \mathrm{~h}$ confirmed our expectations of improved proteolytic stability in the 13-16 set, in contrast to poor survival for all-L counterparts $(5,6,9$, and 10) (Figure S2a). More relevantly, 13-16 maintained the $\mathrm{CB}_{1} \mathrm{R}-5 \mathrm{HT}_{2 \mathrm{~A}} \mathrm{R}$ heteromer-disturbing ability (Figure 2c) and blocking of cross-antagonism and negative cross-talk (Figure 2f,i), as somehow expected from the stereochemical nonmodification of the membrane-embedded TM segments.

BBB Translocation. In our earlier report, ${ }^{18}$ tacitly assuming the inability of TM5-Tat and Tat-TM6 to traverse the BBB, these peptides were administered by intracerebroventricular (ICV) infusion, an invasive route of little interest for human therapeutic application. However, for a peptide drug to be a successful candidate, BBB-crossing capability is mandatory. Therefore, to explore the BBB-crossing features of optimized peptides 13-16, their 5(6)-carboxyfluoresceinlabeled versions (see Experimental Section) were tested for translocation in an in vitro BBB model using mouse b.End3 cells. $^{30,31}$ Fluorescence intensity readings at the basolateral chamber of the transwell device showed that 13 and 15 , with the TM-altering sequence fused to D-CPP motif aGilkrw, translocated more efficiently than 14 and 16, where the TMaltering sequence was fused to the sksksk vector (Figure S2b). 
The high in vitro BBB integrity observed after $24 \mathrm{~h}$ incubation ruled out paracellular transport (Figure S2c). In parallel, cytotoxicity studies on b.End3 cells were conducted to discard potential toxic effects modifying barrier permeability, that is, artifactual peptide ability to cross the BBB (Figure S2d).

Applying Configurational Switch and Sequence Reversal for Last-Stage Lead Optimization. Although considerable progress had been achieved in terms of BBBcrossing, in the CPP-enabled constructs delivering short TM payloads to the $\mathrm{CB}_{1} \mathrm{R}-5 \mathrm{HT}_{2 \mathrm{~A}} \mathrm{R}$ heteromer, the essential modifying segments (i.e., short TM5: VYAYMYILW and short TM6: KTLVLILVV) were still made up of natural Lamino acids, susceptible to endopeptidases such as chymotrypsin, thermolysin, or pepsin, targeting preferentially hydrophobic and/or aromatic residues (Ile, Leu, Val, Ala, Met, Trp, and Tyr) whose abundance in those TM sequences was an important concern. To boost protease resistance, both in body fluids and within the target cell, we developed two last-stage candidates (peptides 17-18, Table S4) where the optimal BBB-permeable shuttle (i.e., aGilkrw) was fused to the retroenantio ( $\mathrm{r} / \mathrm{e}$ ) versions of the TM5- and TM6-altering sequences (i.e., short TM5 and short TM6 composed of Damino acids in the reversed sequence). In such an arrangement (Figure 3), if the all-L sequence is displayed in the conventional
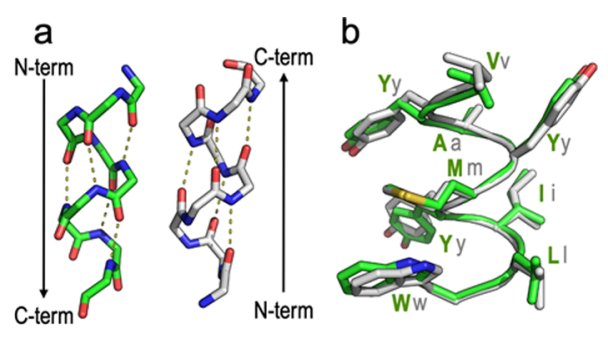

VYAYMYILW WLIYMYAYV

\section{VYAYMYILW wliymyayv}

Figure 3. (a) Retro modification of a short TM5 peptide (VYAYMYILW) where the peptide sequence has been synthesized in the reverse order (WLIYMYAYV). (b) When the enantio modification (D-amino acids) is additionally applied (wliymyayv), the orientation of the side chains is similar to that of the original peptide.

$\mathrm{N}$ - to C-terminal fashion but the $\mathrm{r}$ /e analogue is laid out in the opposite (C-to $\mathrm{N}$-terminal) sense by way of a $180^{\circ}$ rotation in the plane, the side chains adopt similar orientations, ${ }^{32-35}$ although the amide bonds show inverted (CONH vs NHCO) directions. In summary, peptides 17-18, recapitulating the various rounds of structural elaboration so far, met a priori all desired requirements, including (i) the same TM5/TM6 side chain orientation than previous $\mathrm{CB}_{1} \mathrm{R}-5 \mathrm{HT}_{2 \mathrm{~A}} \mathrm{R}$-modifying analogues, (ii) high proteolytic resistance as expected from an all-D composition, ${ }^{36}$ and (iii) ability to traverse the BBB. ${ }^{30}$

When 17 and 18 were submitted to the same screens as previous candidates (Figure 4), our expectations were fulfilled. The ability to interfere the $\mathrm{CB}_{1} \mathrm{R}-5 \mathrm{HT}_{2 \mathrm{~A}} \mathrm{R}$ heterodimer structure and signaling (Figure $4 \mathrm{a}, \mathrm{b}$ ) was preserved, serum degradation was successfully averted (Figure S3a), and despite the extensive structural modifications undergone, BBB-crossing properties were also maintained (Figures $4 \mathrm{c}, \mathrm{d}, \mathrm{S} 3 \mathrm{~b}$ ). This last feature was further confirmed by examining internalization of both 17 and 18 in bEnd.3 cells by confocal microscopy (Figure $4 \mathrm{e})$.

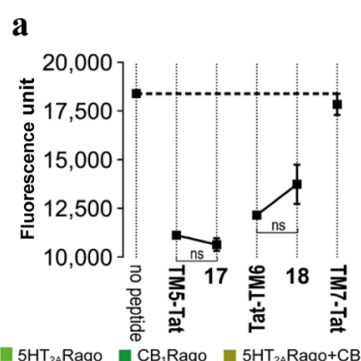

b

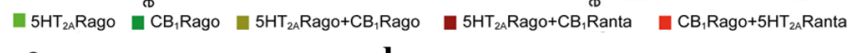
c

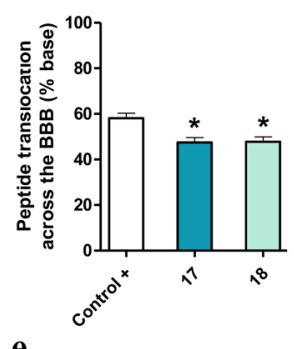

d

$\mathbf{e}$
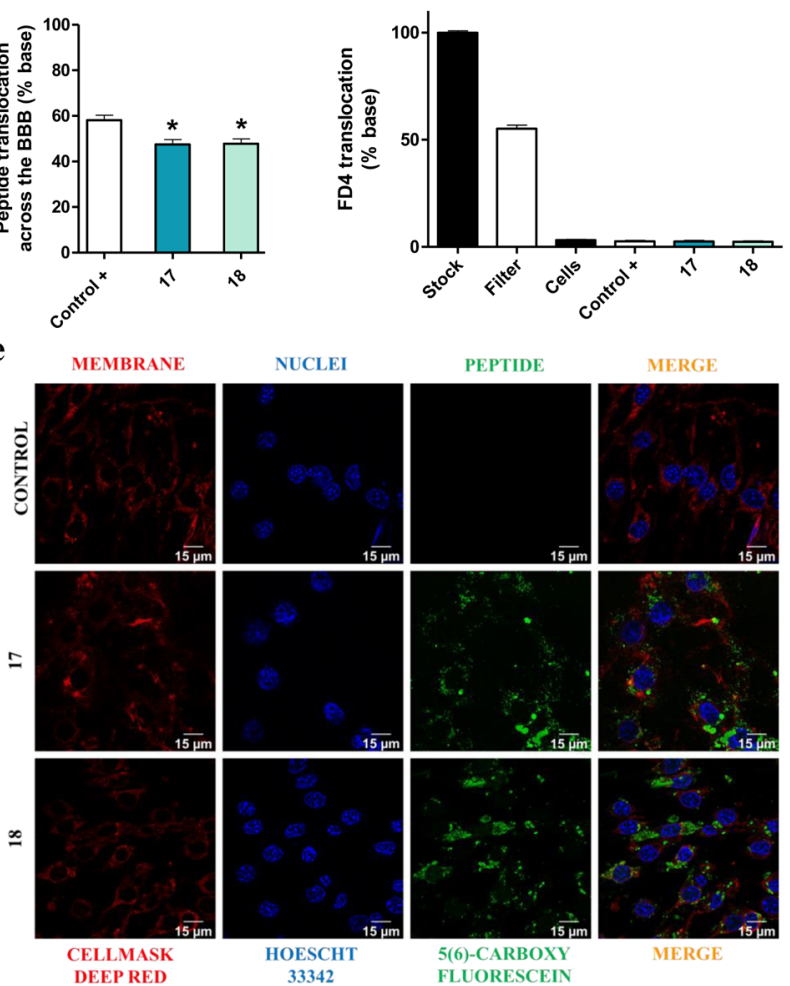

FLUORESCEIN

Figure 4. (a) BiFC analysis of the effect of peptides 17 and 18 on $\mathrm{CB}_{1} \mathrm{R}-5 \mathrm{HT}_{2 \mathrm{~A}} \mathrm{R}$ heteromerization. Fluorescence $(530 \mathrm{~nm})$ of HEK$293 \mathrm{~T}$ cells transfected with $5 \mathrm{HT}_{2 \mathrm{~A}} \mathrm{R}$-cYFP and $\mathrm{CB}_{1} \mathrm{R}-\mathrm{nYFP}$ treated with a vehicle or peptide. Values are mean \pm SEM of $n=10-30$. TM5-Tat and Tat-TM6 are positive controls, whereas TM7-Tat is a negative control; ns (no significant), (one-way ANOVA followed by Tukey's multiple comparison tests). (b) Effect of peptides 17 and 18 on cAMP production. Transfected cells preincubated with a vehicle (no peptide) or with $5 \mathrm{HT}_{2 \mathrm{~A}} \mathrm{R}\left(5 \mathrm{HT}_{2 \mathrm{~A}}\right.$ Rago, DOI, $100 \mathrm{nM}$ ) or $\mathrm{CB}_{1} \mathrm{R}$ $\left(\mathrm{CB}_{1}\right.$ Rago, WIN, $\left.100 \mathrm{nM}\right)$ agonists or with $5 \mathrm{HT}_{2 \mathrm{~A}} \mathrm{R}\left(5 \mathrm{HT}_{2 \mathrm{~A}}\right.$ Ranta, MDL, $300 \mathrm{nM}$ ) or $\mathrm{CB}_{1} \mathrm{R}\left(\mathrm{CB}_{1}\right.$ Ranta, RIM, $\left.1 \mu \mathrm{M}\right)$ antagonists and combinations thereof, in the presence of FK. Values are mean \pm SEM of $n=3-6$ of FK-treated cells. Two-way ANOVA followed by Tukey's multiple comparison tests was used to analyze the data (Table S5). (c) In vitro translocation of peptides 17 and $\mathbf{1 8}$. Translocation (\%) across the transwell BBB model quantified as fluorescence in the basolateral chamber after $24 \mathrm{~h}$. A trans-BBB peptide was used as the positive control. Values are mean \pm SEM of $n$ $=3-6$. ${ }^{*} p<0.05$ s positive control (one-way ANOVA followed by Dunnett post hoc tests). (d) BBB integrity to peptides 17 and 18 . Measured as permeability of fluorescent FD4 dextran upon peptide exposure. Values are mean \pm SEM of $n=3-6$. No statistical significance difference was observed between samples (one-way ANOVA followed by Tukey's multiple comparison test). (e) Confocal microscopy. Images showing peptide internalization into bEnd.3 cells.

In Vivo Validation of Finalist Peptides 17 and 18. The promising in vitro data obtained for analogues 17 and 18 

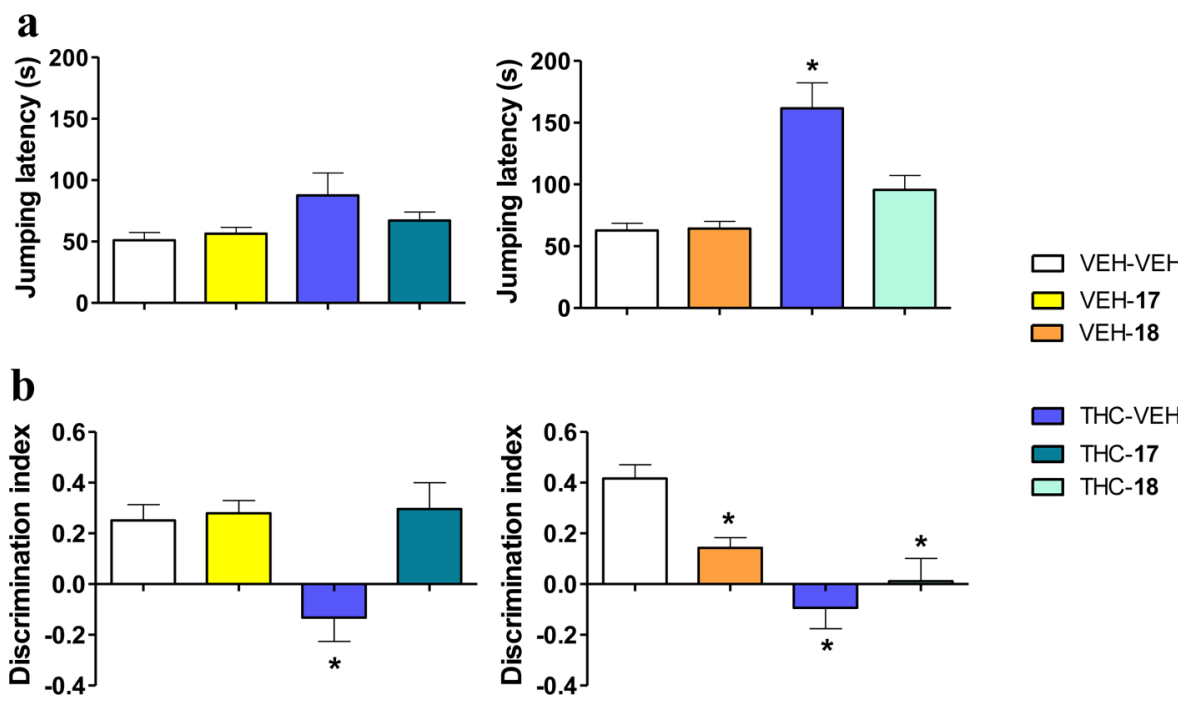

Figure 5. Prevention of THC-induced amnesic effects by peptide 17, while maintaining THC analgesic responses. (a) Analgesic effects of THC (10 $\mathrm{mg} / \mathrm{kg}, \mathrm{IP}$ ) in the mouse hot-plate test were preserved after pretreatment with peptides 17 and 18 (both $20 \mathrm{mg} / \mathrm{kg}, \mathrm{IV}$ ). (b) Amnesic effects of THC $(3 \mathrm{mg} / \mathrm{kg}$, IP) observed in the mouse novel object recognition test were abrogated by pretreatment with $17(20 \mathrm{mg} / \mathrm{kg}$, IV) but not with 18 $(20 \mathrm{mg} / \mathrm{kg}, \mathrm{IV})$. Data are presented as mean \pm SEM $(n=10-12) .{ }^{*} p<0.05 v s$ vehicle + vehicle (Fisher LSD test).

encouraged us to validate their in vivo efficacy in mice. Given their BBB-crossing features, we evaluated the efficacy of the peptides, intravenously (IV) administered, by examining the preservation of THC analgesic effects (hot-plate test) and the disruption of its amnesic effects (novel object recognition paradigm) (see Experimental Section for a detailed description of both assays).

The in vitro-based expectations for $\mathbf{1 7}$ and $\mathbf{1 8}$ were partially fulfilled. Thus, the analgesic effects induced by THC (10 mg/ $\mathrm{kg}$ by intraperitoneal route, IP) were preserved when coadministered with either peptide $(20 \mathrm{mg} / \mathrm{kg}$, IV) (Figure 5a). In contrast, the memory impairment produced by THC (3 $\mathrm{mg} / \mathrm{kg}$, IP) was suppressed only when coadministered with 17 $(20 \mathrm{mg} / \mathrm{kg}, \mathrm{IV})$, but amnesic effects remained unaffected when THC was coadministered with $18(20 \mathrm{mg} / \mathrm{kg}$, IV) (Figure $5 \mathrm{~b})$.

Therefore, peptide 17 was chosen to evaluate the effects following oral administration (OR), the suitable route for therapeutic purposes. THC $(10 \mathrm{mg} / \mathrm{kg}$, IP) analgesic effects remained unaffected by coadministration with 5,10 , and 20 $\mathrm{mg} / \mathrm{kg}(\mathrm{OR})$ doses of 17 (Figure 6a), whereas amnesic effects ( $3 \mathrm{mg} / \mathrm{kg}$ THC, IP) were reverted by the same doses of 17 given by gavage (Figure $6 \mathrm{~b}$ ), demonstrating the effectiveness of the peptide by the most desirable route of administration.

Non-immunogenicity Confirmed. After showing that peptide 17 epitomized our wish list for an optimal Cannabiscomplementing drug candidate, a final concern was its possible immunogenicity, despite expectations that a small 16-residue peptide would most likely go undetected by the immune system. To this end, we immunized mice using a repeated schedule with a high dosage (100 $\mu \mathrm{g}$ of 17 on 5 consecutive days, and a boost at day 15). As shown in Figure 7, repeated administration of $\mathbf{1 7}$ in the free form did not evoke any detectable immune response. Antibodies to 17 could only be eventually raised by immunization with the keyhole limpet hemocyanin $(\mathrm{KLH})$-conjugated version, a positive control of immunogenicity that is, on the other hand, irrelevant with regard to administration of $\mathbf{1 7}$ as a therapeutic agent.

In sum, our research has led to an orally active, proteolytically stable, and nonimmunogenic short peptide

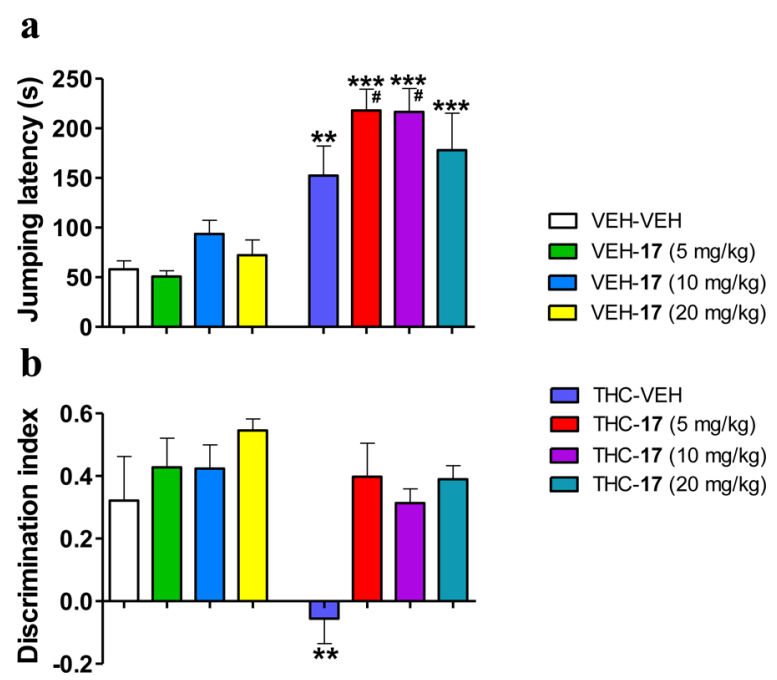

Figure 6. Prevention of THC-induced amnesic effects by peptide 17 administered orally, while maintaining THC analgesic responses. (a) Analgesic effects of THC $(10 \mathrm{mg} / \mathrm{kg}$, IP) revealed in the mouse hotplate test were preserved after pretreatment with $17(5,10$, and 20 $\mathrm{mg} / \mathrm{kg}, \mathrm{OR}$ ). (b) Amnesic effects of THC (3 mg/kg, IP) observed in the mouse novel object recognition test were abrogated by pretreatment with $17(5,10$, and $20 \mathrm{mg} / \mathrm{kg}, \mathrm{OR})$. Data are presented as mean $\pm \operatorname{SEM}(n=5-8) . * * p<0.01, * * * p<0.001 v s$ vehicle + vehicle. ${ }^{\#} p<0.05 v s$ vehicle + THC (Fisher LSD test).

that constitutes an optimal candidate for combined administration with THC, taking advantage of its analgesic effects but avoiding its associated cognitive impairment.

\section{DISCUSSION}

$\mathrm{CB}_{1} \mathrm{R}$ is the most-abundant GPCR in the mammalian brain and the main target of THC. ${ }^{37-40}$ While originally thought to exist exclusively as a monomer, ${ }^{41}$ strong evidence has accumulated indicating its ability to form homo- and heterodimer complexes ${ }^{42-48}$ with new pharmacological and functional properties. ${ }^{49}$ Of particular relevance in this regard is the formation of the $\mathrm{CB}_{1} \mathrm{R}-5 \mathrm{HT}_{2 \mathrm{~A}} \mathrm{R}$ heteromer, as previously 


\section{a}

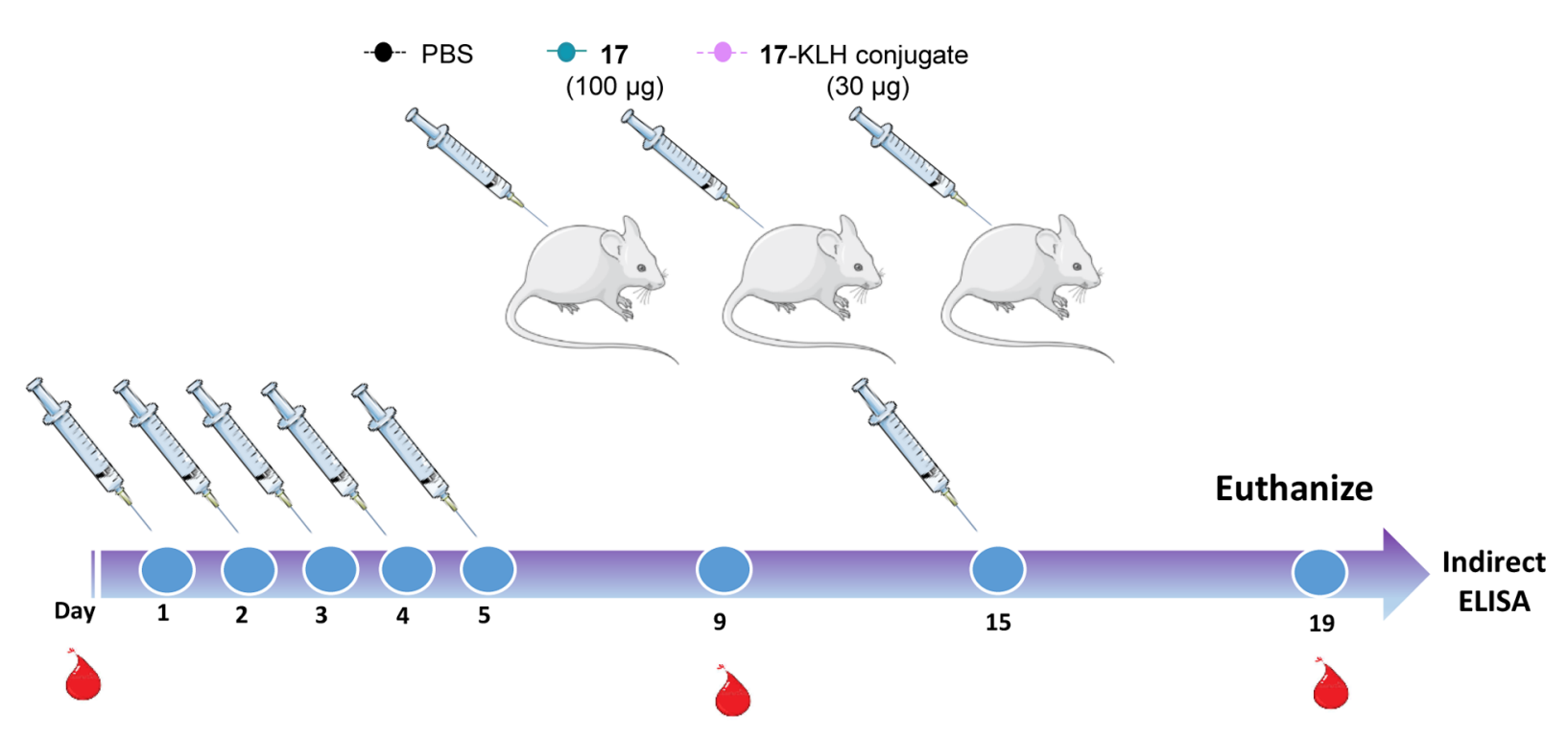

b
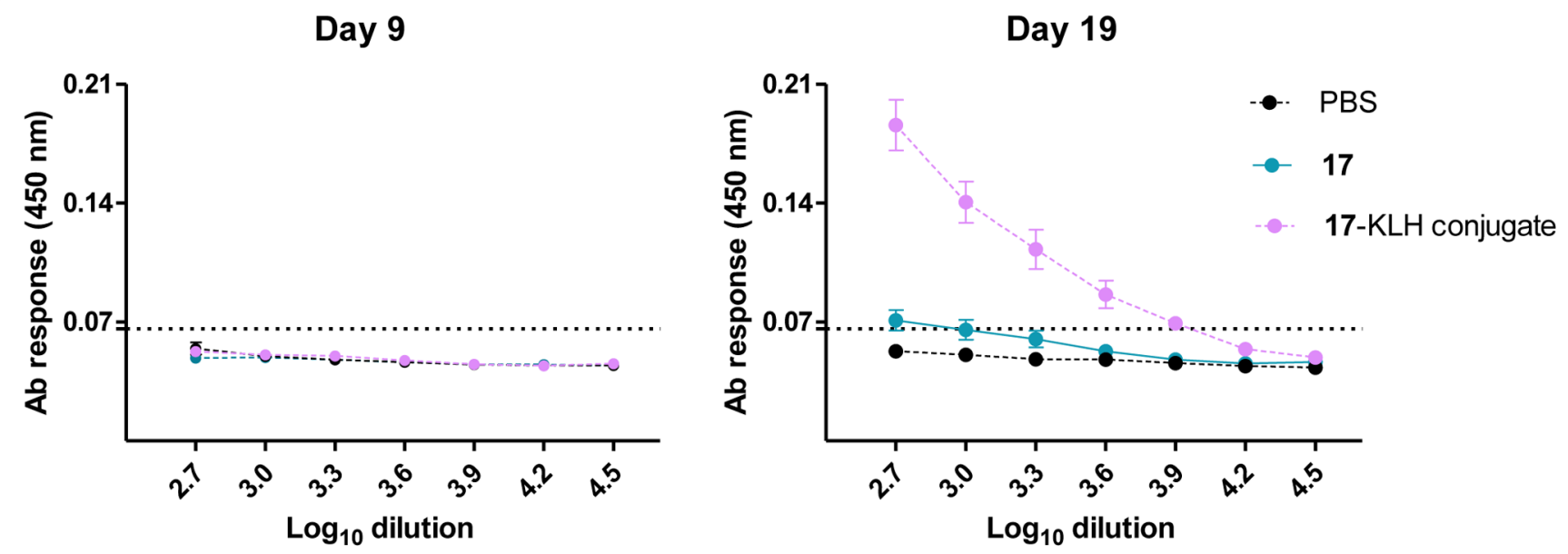

Figure 7. (a) Immunogenicity assessment. The procedure was devised to mimic a daily chronic pain therapy. Mice were treated for 5 consecutive days and boosted at day 15 with peptide 17 in phosphate-buffered saline (PBS) (group 1, $100 \mu \mathrm{g} /$ dose), peptide 17-KLH conjugate in PBS (group 2, positive control, $30 \mu \mathrm{g}$ ), or PBS (group 3, negative control). The lower dose of the 17-KLH conjugate, compared to 17 alone, was chosen to prevent potential protein toxicity in the mice. Serum samples were collected on days 0, 9, and 19 and animals were euthanized on day 19. (b) ELISA of humoral response. Peptide-specific antibody response in sera collected at the indicated days. Each point depicts mean antibody titers \pm $\mathrm{SD}$. The dotted line indicates the detection limit. Free (nonconjugated) 17 induces no significant response; immunogenicity is observed only upon conjugation to a large-size carrier protein ( $\mathrm{KLH}, \mathrm{MW} \sim 5 \mathrm{MDa})$ and boosting.

revealed by (i) in vitro proximity-based biophysical techniques, (ii) specific biochemical signatures of heteromers distinct from those of the protomers, (iii) in situ proximity ligation assay to detect protein-protein interactions in native tissues, (iv) membrane-permeable peptides altering heteromeric interfaces, and (v) mice expressing heteromerization-deficient receptors, all of them established criteria for the existence of $\mathrm{CB}_{1} \mathrm{R}-5 \mathrm{HT}_{2 \mathrm{~A}} \mathrm{R}$ heteromers in vivo. ${ }^{50}$ This $\mathrm{CB}_{1} \mathrm{R}-5 \mathrm{HT}_{2 \mathrm{~A}} \mathrm{R}$ heteromer, therefore, is not simply due to receptor overexpression, but the consequence of an explicit molecular mechanism of THC to dissociate beneficial antinociceptive response and detrimental amnesic effects, ${ }^{50}$ hence defining it as a novel therapeutic target.

The development of heteromer-specific drugs is more challenging than traditional drug-discovery programs, where efforts are focused on compounds binding on orthosteric sites of monomeric GPCRs of endogenous ligands. ${ }^{51,52}$ One of the most widespread options to target heteromers is designing bivalent ligands, that is, single chemical entities capable of interacting simultaneously with the orthosteric sites of a (homo/hetero) dimer via two pharmacophore units covalently linked by an appropriate spacer. ${ }^{53,54}$ We have developed here a new approach in which the ligand/peptide binds at the TM dimerization interface of the heteromer. This rests on the assumption of allosteric binding sites at the extrahelical part of GPCRs, facing the membrane bilayer. The numerous recent structures of GPCRs bound to allosteric modulators have confirmed the presence of these sites for families A and $\mathrm{B} .{ }^{55}$ Related to the GPCRs of this manuscript, the negative allosteric modulator ORG27569 of $\mathrm{CB}_{1} \mathrm{R}$ binds to an extrahelical site, mostly interacting with TM4. ${ }^{56}$

Protein-protein interfaces in general, and GPCR interfaces in particular, consist of large and flat contact areas with no well-defined pockets. ${ }^{57}$ Here, we have taken advantage of our previous studies in which peptides with the TM5 and TM6 sequences of $\mathrm{CB}_{1} \mathrm{R}$ (TM5-Tat and Tat-TM6), fused to a HIV- 
Tat CPP vector, can bind $5 \mathrm{HT}_{2 \mathrm{~A}} \mathrm{R}$ and modify the quaternary structure of the $\mathrm{CB}_{1} \mathrm{R}-5 \mathrm{HT}_{2 \mathrm{~A}} \mathrm{R}$ heteromer. ${ }^{18} \mathrm{MD}$ simulations of TM5-Tat and Tat-TM6 in complex with $5 \mathrm{HT}_{2 \mathrm{~A}} \mathrm{R}$ have allowed to identify these "hotspots" near the intracellular part.

The proteolytic instability of TM5-Tat or Tat-TM6 and their inability to penetrate the BBB complicate any prospect of systemic administration. With this in mind, we have set out to develop strategies aimed at improving the druggability of the TM5-Tat and Tat-TM6 prototypes by (i) downsizing the length of the interfering peptides to only include the essential identified "hotspots", (ii) enabling CNS delivery via a BBBpermeating CPP shuttle, (iii) ensuring proteolytic robustness, hence bioavailability, by judicious structural manipulation, including the switch to enantio and retro-enantio versions of CPP and interfering motifs, respectively. To this end, we have used in silico tools and peptide medicinal chemistry criteria through a series of design/optimization rounds and a variety of in vitro and in vivo screens that have eventually allowed to identify peptide wliymyayvaGilkrw (17) as a highly effective, orally available candidate with encouraging therapeutic prospects.

\section{CONCLUSIONS}

Pain is a highly relevant pharmacological area with still significant unmet needs. It has been suggested that the therapeutic gap between benign but rather feeble NSAID painkillers and effective but high-risk opioids could be ideally bridged by cannabinoids, although their important undesirable side effects represent a major limitation. In addition, new markets are emerging, also aimed at using cannabis-derived products with other (i.e., non pain-related) purposes, and again entraining significant risks associated to these side effects. Our work has resulted in a novel tool to minimize the most prominent of these adverse outcomes, namely cognitive impairment. We specifically propose a new approach based on the administration of a $\mathrm{CB}_{1} \mathrm{R}$ cannabinoid agonist (e.g., THC) in combination with a $\mathrm{CB}_{1} \mathrm{R}-5 \mathrm{HT}_{2 \mathrm{~A}} \mathrm{R}$ altering agent. This compound is a 16-residue peptide (17: wliymyayvaGilkrw) that provides a convincing proof of concept that appropriately modified peptides constitute valid therapeutic candidates for treating pain with cannabinoids minimizing their side effects. This novel pharmacological approach could also be of interest for attenuating the side effects associated to the use of cannabis derivatives for other purposes.

\section{EXPERIMENTAL SECTION}

Computational Models. The $\mathrm{CB}_{1} \mathrm{R}-5-\mathrm{HT}_{2 \mathrm{~A}} \mathrm{R}$ heteromer (Figure 1a) was built from the TM5/6 dimeric interface observed in the crystal structure of the $\mu$-opioid receptor (PDB id 4DKL), ${ }^{21}$ using the crystal structure of $\mathrm{CB}_{1} \mathrm{R}(5 \mathrm{TGZ})^{58}$ and a $5 \mathrm{HT}_{2 \mathrm{~B}}$-based $(4 \mathrm{IB} 4)^{59}$ homology model of $5 \mathrm{HT}_{2 \mathrm{~A}} \mathrm{R}$ as previously proposed. ${ }^{18,20}$ The molecular $3 \mathrm{D}$-coordinates corresponding to $\mathrm{CB}_{1} \mathrm{R}$ TM helices 5 and 6 were extracted and fused with the HIV-Tat(48-58) motif. The resulting TM5-Tat and Tat-TM6 peptides were capped at the $\mathrm{N}$ - and $\mathrm{C}$-termini with acetyl and carboxamide groups and energy-minimized using the Molecular Operating Environment (MOE) software (Chemical Computing Group Inc., Montreal, Quebec, Canada). Molecular complexes of $5 \mathrm{HT}_{2 \mathrm{~A}} \mathrm{R}$ with TM5-Tat and Tat-TM6 were embedded in a pre-equilibrated lipid bilayer box containing 1palmitoyl-2-oleoyl-sn-glycero-3-phosphatidylcholine (POPC), water molecules (TIP3P), and monoatomic $\mathrm{Na}^{+}$and $\mathrm{Cl}^{-}$ions $(0.2 \mathrm{M})$ (Figure $1 \mathrm{~b}, \mathrm{c}$ ). The assignment of ionization states and hydrogens at physiological $\mathrm{pH}$ for the selected structures was conducted with the Protonate3D method as implemented in MOE. Molecular systems were subject to 1000 cycles of energy minimization, followed by $20 \mathrm{~ns}$ of gradual relaxation of positional restraints (corresponding to 100 , 50,25 , and $10 \mathrm{~kJ} \mathrm{~mol}^{-1} \mathrm{~nm}^{-2}$ ) at protein backbone coordinates before the production phase in order to hydrate the receptor cavities and allow lipids to pack around the protein. The AMBER99SB force field as implemented in GROMACS and Berger parameters for POPC lipids were used for the MD simulations. After equilibration, three replicas of $1 \mu \mathrm{s}$ of unrestrained MD simulation were performed at a constant temperature of $300 \mathrm{~K}$ and a time step of 2.0 fs. LennardJones interactions were computed using a cutoff of $10 \AA$, and the electrostatic interactions were treated using PME with the same realspace cutoff under periodic boundary conditions. MD simulations were performed using GROMACS 2019.

Peptide Synthesis, Analysis, and Purification. Peptides were assembled in a Prelude instrument (Protein Technologies, Tucson, AZ) running optimized Fmoc synthesis protocols as described before. $^{60}$ For labeled peptides, the incorporation of 5(6)-carboxyfluorescein to the carboxy-terminal end was performed by adding an additional Fmoc-Lys(Mtt)-OH residue to the sequence, the Mtt group selectively removable on-resin with $1 \%$ trifluoroacetic acid, after which the fluorescent dye was coupled via its carboxyl function to the Lys free $\varepsilon-\mathrm{NH}_{2}$ group. Final deprotection and cleavage were performed with a $\mathrm{CF}_{3} \mathrm{COOH} / \mathrm{H}_{2} \mathrm{O} / 3$,6-dioxa-1,8-octanedithiol/ triisopropylsilane $(94: 2.5: 2.5: 1 \mathrm{v} / \mathrm{v})$ cocktail for $90 \mathrm{~min}$. Peptide analysis and purification were performed as previously detailed. ${ }^{60}$ Fractions of satisfactory purity $(>90 \%)$ by analytical high-performance liquid chromatography (HPLC) were pooled, lyophilized, and analyzed for identity by HPLC-MS (Supporting Information, section 3). For immunogenicity studies, conjugation to bovine serum albumin (BSA) or KLH was carried out with a peptide containing an extra Cterminal Cys residue. Both carrier proteins were preactivated with $\mathrm{m}$ maleimidobenzoyl- $N$-hydroxysuccinimide ester (MBS). After Sephadex G25 gel filtration, purified KLH-MBS or BSA-MBS was added to the peptide (r.t., $5 \mathrm{~h}, \mathrm{pH}$ 7.0). The unreacted peptide was removed by dialysis and the peptide-protein conjugates were lyophilized and quantified by the AccQTag method.

Enzyme Digestion. Peptide samples, incubated with trypsin, were collected and analyzed as before. ${ }^{60}$ For human serum digestion, peptide [1000 $\mu \mathrm{M}, 2 \%$ dimethyl sulfoxide (DMSO) in filtered $\mathrm{H}_{2} \mathrm{O}$ ] was added to human serum (Sigma, St Louis, Missouri) in a 1:1 ratio and incubated at $37{ }^{\circ} \mathrm{C}$ with gentle shaking. At 0 min and $24 \mathrm{~h}$, aliquots were taken and proteolysis was stopped with $\mathrm{CH}_{3} \mathrm{CN}(80 \%$ in filtered $\mathrm{H}_{2} \mathrm{O}$ ), chilled at $0{ }^{\circ} \mathrm{C}$ for $15 \mathrm{~min}$ to precipitate serum proteins, and centrifuged at $13,000 \mathrm{rpm}$ at $4{ }^{\circ} \mathrm{C}$ for $10 \mathrm{~min}$. The supernatant was collected and analyzed by analytical RP-HPLC and LC-MS as described before, ${ }^{60}$ with a $0-95 \%$ linear gradient of $\mathrm{CH}_{3} \mathrm{CN}$ over $15 \mathrm{~min}$. All experiments are performed in duplicate and data were fitted with GraphPad Prism.

In Vitro Biochemical and Molecular Assays. Expression Vectors, HEK-293T Cell Culture, and Transient Transfection. Sequences encoding YFP Venus protein amino acid residues 1-155 and 156-238 were subcloned in the pcDNA3.1 vector to obtain the YFP Venus hemitruncated proteins. The human cDNAs for $5 \mathrm{HT}_{2 \mathrm{~A}} \mathrm{R}$ and $\mathrm{CB}_{1} \mathrm{R}$, cloned into the pcDNA3.1, were amplified and subcloned as described ${ }^{18}$ to give $5 \mathrm{HT}_{2 \mathrm{~A}} \mathrm{R}$-cYFP and $\mathrm{CB}_{1} \mathrm{R}-\mathrm{nYFP}$. Human embryonic kidney (HEK-293T) cells obtained from ATCC were grown in Dulbecco's modified Eagle's medium (DMEM) (Gibco) supplemented with $2 \mathrm{mM}$ L-glutamine, $100 \mu \mathrm{g} / \mathrm{mL}$ sodium pyruvate, $100 \mathrm{U} / \mathrm{mL}$ penicillin/streptomycin, MEM nonessential amino acid solution $(1 / 100)$, and $5 \%(\mathrm{v} / \mathrm{v})$ heat-inactivated fetal bovine serum (FBS) (all supplements from Invitrogen, Paisley, Scotland, UK). Cells were maintained at $37{ }^{\circ} \mathrm{C}$ in an atmosphere of $5 \% \mathrm{CO}_{2}$. HEK-293T cells were transfected with the corresponding fusion protein cDNA by the polyethylenimine (Sigma) method, as described before. ${ }^{18}$

BiFC Assay. HEK-293T cells, after $48 \mathrm{~h}$ transient cotransfection with the cDNA encoding for $5 \mathrm{HT}_{2 \mathrm{~A}} \mathrm{R}$, fused to $\mathrm{c}-\mathrm{YFP}$, and $\mathrm{CB}_{1} \mathrm{R}$ fused to n-YFP ( $4 \mu \mathrm{g}$ of cDNA for each construct), were treated or not with the indicated peptides $(4 \mu \mathrm{M})$ for $4 \mathrm{~h}$ at $37^{\circ} \mathrm{C}$. To quantify protein-reconstituted YFP Venus expression, cells $(20 \mu \mathrm{g}$ protein $)$ were distributed in 96-well microplates (black plates with a 
transparent bottom, Porvair, King's Lynn, UK), and emission fluorescence at $530 \mathrm{~nm}$ was read in a Fluo Star Optima fluorimeter (BMG Labtechnologies, Offenburg, Germany) equipped with a highenergy Xe flash lamp, using a $10 \mathrm{~nm}$ bandwidth excitation filter at 400 $\mathrm{nm}$ reading. Protein fluorescence expression was determined as fluorescence of the sample minus the fluorescence of cells not expressing the fusion proteins (basal). Cells expressing $5 \mathrm{HT}_{2 \mathrm{~A}} \mathrm{R}$ cVenus and nVenus or $\mathrm{CB}_{1} \mathrm{R}-\mathrm{nVenus}$ and cVenus showed similar fluorescence levels to nontransfected cells.

CAMP Production and ERK-1/2 Phosphorylation Assays. For cAMP production, homogeneous time-resolved fluorescence energy transfer (HTRF) assays were performed as previously described. ${ }^{\text {. }}$ Cells (1000 cells/well) growing in medium containing $50 \mu \mathrm{M}$ zardeverine were pretreated with the $\mathrm{CB}_{1} \mathrm{R}$ antagonist, RIM $(1 \mu \mathrm{M}$, $\mathrm{RIM}$ ), and the 5- $\mathrm{HT}_{2 \mathrm{~A}} \mathrm{R}$ antagonist, MDL 100,907 (300 nM, MDL), or the corresponding vehicle in white ProxiPlate 384-well microplates (PerkinElmer, Waltham, Massachusetts, US) at $25^{\circ} \mathrm{C}$ for $20 \mathrm{~min}$ and stimulated with the CB1 agonist, WIN 55,212-2 (100 nM, WIN) and the $5 \mathrm{HT}_{2 \mathrm{~A}}$ agonist, DOI (100 nM, DOI) for $15 \mathrm{~min}$ before adding 0.5 $\mu \mathrm{M} \mathrm{FK}$, or vehicle and incubated for an additional 15 min period. Fluorescence at $665 \mathrm{~nm}$ was analyzed on a PHERAstar Flagship microplate reader equipped with an HTRF optical module (BMG Lab technologies, Offenburg, Germany).

For ERK-1/2 phosphorylation assay, HEK-293 cells (30.000 cells/ well) seeded in 96-well poly-D-lysine-coated plates (Sigma-Aldrich, Madrid, Spain) were pretreated at $25^{\circ} \mathrm{C}$ for 15 min with RIM $(1 \mu \mathrm{M}$, RIM) and MDL 100,907 (300 nM, MDL) or the corresponding vehicle and stimulated for an additional $7 \mathrm{~min}$ with the WIN 55,212-2 $(100 \mathrm{nM}, \mathrm{WIN})$ and DOI $(100 \mathrm{nM}$, DOI). Phosphorylation was determined in white ProxiPlate 384-well microplates (PerkinElmer Life Sciences) by the $\alpha$-screen bead-based technology using the amplified luminescent proximity homogeneous assay kit (PerkinElmer Life Sciences) and using the Enspire multimode plate reader (PerkinElmer Life Sciences). Phosphorylation is expressed in arbitrary units, ALPHAcounts, as measured by light emission at $520-620 \mathrm{~nm}$ of the acceptor beads.

bEnd.3 Cell Culture and Viability Assay. bEnd.3 brain endothelial cells (ATCC CRL-2299TM) were grown as a monolayer in DMEM supplemented with $10 \% \mathrm{FBS}$ and $1 \%$ penicillin/streptomycin solution (Gibco, USA). Cells were cultured in a humidified atmosphere of $95 \%$ air and $5 \% \mathrm{CO}_{2}$ at $37{ }^{\circ} \mathrm{C}$ (MCO-18AIC (UV), Sanyo, Japan), with daily medium replacement.

The cytotoxicity of peptides toward bEnd. 3 cells seeded into a 96well plate (Corning, USA) at 10,000 cells/100 $\mu \mathrm{L} /$ well was tested using CellTiter-Blue cell viability assay. ${ }^{31} \mathrm{IC}_{50}$ values were determined with GraphPad Prism using a log(inhibitor) vs normalized response. Experiments were performed on different days using independently grown cell cultures.

In Vitro BBB Translocation and Integrity Studies. The translocation capabilities of 5(6)-carboxyfluorescein-labeled peptides were determined using a protocol previously described. ${ }^{30,31}$ After the experiment, the integrity of the endothelial barrier was checked by measuring the permeability of a $4 \mathrm{kDa}$ fluorescently labeled dextran (FD4) as previously described. ${ }^{25}$ Experiments were carried out on different days using independently grown cell cultures.

Confocal Microscopy. The internalization of 5(6)-carboxyfluorescein-labeled peptides was evaluated using confocal microscopy as previously described. ${ }^{31}$ The acquisition was done on a confocal pointscanning Zeiss LSM 880 microscope (Carl Zeiss, Germany) equipped with an alpha Plan-Apochromat X 63 oil immersion objective (1.40 numerical aperture). A diode 405-30 laser was used to excite Hoechst 33342 (Sigma-Aldrich, Spain) and CellMask Deep Red plasma membrane stain (Thermo Fisher, USA). The $488 \mathrm{~nm}$ line from an Ar laser was used to excite labeled peptides. In the normal confocal mode, X 0.6 zoom images were recorded at $1024 \times 1024$ resolution. ZEN software was used for image acquisition and Fiji software for image processing.

In Vivo Behavior and Pain Response Assays. Memory Impairment Measurements. On day 1 (Habituation), mice were habituated for 9 min to the V-maze in which the task was performed.
The following day (Training), mice were placed in the V-maze for 9 min, two identical objects were presented and the time that the mice spent exploring each object was recorded. Mice were again placed in the maze $24 \mathrm{~h}$ later for $9 \mathrm{~min}$ (Test), one of the familiar objects was replaced with a novel object and the total time spent exploring each of the two objects (novel and familiar) was recorded. Object exploration was defined as the orientation of the nose to the object at less than 2 $\mathrm{cm}$. A discrimination index was calculated as the difference between the time spent exploring the novel or familiar object divided by the total time exploring the two objects. A higher discrimination index is considered to reflect greater memory retention for the familiar object.

Peptide or vehicle were administered by IV $(20 \mathrm{mg} / \mathrm{kg})$ or oral route $(5,10$, and $20 \mathrm{mg} / \mathrm{kg})$ immediately after the training session. Thirty min after peptide administration, mice received an IP injection of vehicle (5\% v/v of ethanol, $5 \% \mathrm{v} / \mathrm{v}$ of Cremophor-EL, and $90 \% \mathrm{v} / \mathrm{v}$ saline) or $3 \mathrm{mg} / \mathrm{kg}$ of THC dissolved in vehicle.

Hot-Plate Test. THC-induced analgesia was measured using a hotplate meter (Hot/Cold Plate Test, Bioseb, USA) $60 \mathrm{~min}$ after IP injection of either THC dissolved in IP vehicle or vehicle alone. Peptide or vehicle were administered by IV $(20 \mathrm{mg} / \mathrm{kg})$ or oral route $(5,10$ and $20 \mathrm{mg} / \mathrm{kg}) 30 \mathrm{~min}$ before THC. The plate was heated to $52 \pm 0.5{ }^{\circ} \mathrm{C}$ and the time (in s) until mice showed a jumping response on the plate was recorded. A cutoff time of $240 \mathrm{~s}$ was set to prevent tissue damage.

Mice Immunization, Bleedings, and Serum Analysis by ELISA. Experiments were performed at the ICTS "NANBIOSIS" Custom Antibody Service (CAbS, CIBER-BBN, IQAC-CSIC). The immune response to 17 was assessed in outbred Swiss ICR (CD-1) mice strain Hsd:ICR (CD-1) (Envigo RMS, The Netherlands), following the immunization schedule in Figure 7. Animals were housed under standard conditions in the CID-CSIC animal facility. Animal experimental procedures were conducted in accordance with protocols approved by CSIC Committee on Ethics of Animal Experiments and Biosafety, as well as the Spanish National Committee on Ethics and Animal Welfare. Briefly, a first group of 10 female mice received IV doses of $17(200 \mu \mathrm{L}, 20 \mathrm{mg} / \mathrm{kg}, \mathrm{PBS}+2 \%$ DMSO), a second group of 5 mice received IV doses of $17-\mathrm{KLH}$ conjugate $(200 \mu \mathrm{L}, 30 \mu \mathrm{g})$ and a third group of 5 mice received IVdoses of PBS (200 $\mu \mathrm{L}$, negative control). The 17-KLH conjugate, administered with Freund's adjuvant, was also used to generate polyclonal antibody (positive control) (data not shown). Serum samples were collected by tail vein bleeds on days 0,9 , and 19 . The animals were humanely sacrificed on day 19 . The peptide-specific humoral response was determined by indirect ELISA. Microtiter plates (Nunc) were coated with the 17-BSA conjugate $(1 \mu \mathrm{g} / \mathrm{mL}$ in coating buffer, $100 \mu \mathrm{L} /$ well) overnight at $4{ }^{\circ} \mathrm{C}$. The next day, plates were washed and antiserum samples (diluted in PBST, serial dilutions starting at $1 / 100,100 \mu \mathrm{L} /$ well) were added and incubated for $30 \mathrm{~min}$ at r.t.. The plates were again washed and a solution of anti-IgG-HRP $(1 / 4000$ in $10 \mathrm{mM}$ PBST $)$ was added to the wells $(100 \mu \mathrm{L} /$ well $)$ and incubated for $30 \mathrm{~min}$ at r.t.. After another wash, the tetramethylbenzidine substrate solution was added $(100 \mu \mathrm{L} /$ well $)$ to plates. Color development was stopped with $4 \mathrm{~N} \mathrm{H}_{2} \mathrm{SO}_{4}(50 \mu \mathrm{L} /$ well $)$ after $30 \mathrm{~min}$ at r.t., and absorbance read at $450 \mathrm{~nm}$. Titers in a $\log _{10}$ scale were expressed as the reciprocal of the last dilution giving the absorbance recorded in the control wells (serum at day 0 ) plus 2 SD.

Statistical Analysis. Experimental data were managed and analyzed with GraphPad Prism software version 9 (San Diego, CA, USA) or IBM SPSS Statistics version 27.0 (IBM Corp., NY, USA). P-values lower than 0.05 were considered statistically significant.

\section{ASSOCIATED CONTENT}

\section{s) Supporting Information}

The Supporting Information is available free of charge at https://pubs.acs.org/doi/10.1021/acs.jmedchem.1c00484.

Design and synthesis of TMs 5 and 6 short analogues; HIV-Tat replacement by shorter CPPs; HIV-Tat replacement by shorter CPPs; applying CPP stereo- 
chemistry change; applying configurational switch and sequence reversal for last-stage lead optimization; statistical analyses used in signaling experiments; stabilities of the peptide-receptor complexes; effect of CPP stereochemistry on trypsin digestion; HPLC analysis of serum-incubated peptides 17 and 18; analytical data; and molecular formula strings (PDF)

Crystal structure of the $\mu$-opioid receptor (PDB)

Molecular formula strings (CSV)

\section{AUTHOR INFORMATION}

\section{Corresponding Authors}

Rafael Maldonado - Department of Experimental and Health Sciences, Universitat Pompeu Fabra, 08003 Barcelona, Spain; Phone: (+34) 933160824;

Email: rafael.maldonado@upf.edu

David Andreu - Department of Experimental and Health Sciences, Universitat Pompeu Fabra, 08003 Barcelona,

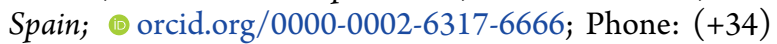
933160868; Email: david.andreu@upf.edu

\section{Authors}

Maria Gallo - Department of Experimental and Health Sciences, Universitat Pompeu Fabra, 08003 Barcelona, Spain; 이이. orid.org/0000-0001-9099-7235

Estefanía Moreno - Department of Biochemistry and Molecular Biomedicine, Institute of Biomedicine, University of Barcelona, 08028 Barcelona, Spain; 다이.org/00000002-2491-5753

Sira Defaus - Department of Experimental and Health Sciences, Universitat Pompeu Fabra, 08003 Barcelona, Spain; (1) orcid.org/0000-0002-3106-458X

Antonio Ortega-Alvaro - Department of Experimental and Health Sciences, Universitat Pompeu Fabra, 08003 Barcelona, Spain

Angel Gonzalez - Laboratori de Medicina Computacional, Unitat de Bioestadística, Facultat de Medicina, Universitat Autònoma de Barcelona, 08193 Bellaterra, Spain

Patricia Robledo - Integrative Pharmacology and Systems Neuroscience, IMIM-Hospital del Mar Research Institute, 08003 Barcelona, Spain

Marco Cavaco - Instituto de Medicina Molecular, Faculdade de Medicina, Universidade de Lisboa, 1649-028 Lisboa, Portugal; (1) orcid.org/0000-0002-0938-9038

Vera Neves - Instituto de Medicina Molecular, Faculdade de Medicina, Universidade de Lisboa, 1649-028 Lisboa, Portugal; (1) orcid.org/0000-0002-2989-7208

Miguel A. R. B. Castanho - Instituto de Medicina Molecular, Faculdade de Medicina, Universidade de Lisboa, 1649-028 Lisboa, Portugal; O orcid.org/0000-0001-7891-7562

Vicent Casadó - Department of Biochemistry and Molecular Biomedicine, Institute of Biomedicine, University of Barcelona, 08028 Barcelona, Spain; 다잉.org/00000002-1764-3825

Leonardo Pardo - Laboratori de Medicina Computacional, Unitat de Bioestadística, Facultat de Medicina, Universitat Autònoma de Barcelona, 08193 Bellaterra, Spain

Complete contact information is available at: https://pubs.acs.org/10.1021/acs.jmedchem.1c00484

\section{Author Contributions}

M.G. and E.M. contributed equally. V.C., L.P., R.M., and D.A. are cosenior authors.

\section{Funding}

Rhodes Pharmaceuticals (L.P., Coventry, R.I., USA; 20162017), Marie Skłodowska-Curie Research and Innovation Staff Exchange (call H2020-MSCA-RISE-2014, 2015-2019), the Spanish Ministry of Economy and Innovation with FEDER funds (SAF2017-87629-R, PID2019-109240RB-I00), and the Fundació Bancària La Caixa (CaixaImpulse 2018 call; 20182020).

\section{Notes}

The authors declare no competing financial interest. Authors will release the atomic coordinates upon article publication.

\section{ACKNOWLEDGMENTS}

The authors thank Dr. Núria Pascual from Custom Antibody Service (CAbS, CIBER-BBN, IQAC-CSIC) for help with immunizations.

\section{ABBREVIATIONS}

BiFC, bimolecular fluorescence complementation; $\mathrm{BBB}$, blood-brain barrier; $\mathrm{CB}_{1} \mathrm{R}$, cannabinoid receptor 1 ; $\mathrm{CNS}$, central nervous system; CPP, cell-penetrating peptide; DOI, 2,5-dimethoxy-4-iodoamphetamine; FK, forskolin; GPCR, Gprotein-coupled receptor; ICV, intracerebroventricular; IP, intraperitoneal; IV, intravenous; KLH, keyhole limpet hemocyanin; MD, molecular dynamics; MDL, MDL 100,907; NSAID, nonsteroidal anti-inflammatory drug; r/e, retro-enantio; $5 \mathrm{HT}_{2 \mathrm{~A}} \mathrm{R}$, serotonin (5-hydroxytryptamine, 5$\mathrm{HT}$ ) receptor $2 \mathrm{~A}$; THC, tetrahydrocannabinol; TM, transmembrane; WIN, WIN 55,212-2; YFP, yellow fluorescent protein

\section{REFERENCES}

(1) Dahlhamer, J.; Lucas, J.; Zelaya, C.; Nahin, R.; Mackey, S.; DeBar, L.; Kerns, R.; Von Korff, M.; Porter, L.; Helmick, C. Prevalence of Chronic Pain and High-Impact Chronic Pain Among Adults - United States, 2016. Morb. Mortal. Wkly. Rep. 2018, 67, 1001-1006.

(2) Scholl, L.; Seth, P.; Kariisa, M.; Wilson, N.; Baldwin, G. Drug and Opioid-Involved Overdose Deaths-United States, 2013-2017. Morb. Mortal. Wkly. Rep. 2018, 67, 1419-1427.

(3) Kaye, A. D.; Jones, M. R.; Kaye, A. M.; Ripoll, J. G.; Galan, V.; Beakley, B. D.; Calixto, F.; Bolden, J. L.; Urman, R. D.; Manchikanti, L. Prescription Opioid Abuse in Chronic Pain: An Updated Review of Opioid Abuse Predictors and Strategies to Curb Opioid Abuse: Part 1. Pain Physician 2017, 2, S93-S109.

(4) Harirforoosh, S.; Asghar, W.; Jamali, F. Adverse Effects of Nonsteroidal Antiinflammatory Drugs: An Update of Gastrointestinal, Cardiovascular and Renal Complications. J. Pharm. Pharm. Sci. 2013, $16,821-847$.

(5) Carter, G. T.; Duong, V.; Ho, S.; Ngo, K. C.; Greer, C. L.; Weeks, D. L. Side Effects of Commonly Prescribed Analgesic Medications. Phys. Med. Rehabil. Clin. N. Am. 2014, 25, 457-470.

(6) Walker, J. M.; Hohmann, A. G. Cannabinoid Mechanisms of Pain Suppression. Handb. Exp. Pharmacol. 2005, 168, 509-554.

(7) Valjent, E.; Mitchell, J. M.; Besson, M.-J.; Caboche, J.; Maldonado, R. Behavioural and biochemical evidence for interactions between $\Delta 9$-tetrahydrocannabinol and nicotine. Br. J. Pharmacol. 2002, 135, 564-578.

(8) de Fonseca, F. R.; Rubio, P.; Menzaghi, F.; Merlo-Pich, E.; Rivier, J.; Koob, G. F.; Navarro, M. Corticotropin-Releasing Factor (CRF) Antagonist [D-Phe12,Nle21,38,C Alpha MeLeu37]CRF 
Attenuates the Acute Actions of the Highly Potent Cannabinoid Receptor Agonist HU-210 on Defensive-Withdrawal Behavior in Rats. J. Pharmacol. Exp. Ther. 1996, 276, 56-64.

(9) Kandasamy, R.; Dawson, C. T.; Craft, R. M.; Morgan, M. M. Anti-Migraine Effect of (9)-Tetrahydrocannabinol in the Female Rat. Eur. J. Pharmacol. 2018, 818, 271-277.

(10) Baron, E. P.; Lucas, P.; Eades, J.; Hogue, O. Patterns of Medicinal Cannabis Use, Strain Analysis, and Substitution Effect among Patients with Migraine, Headache, Arthritis, and Chronic Pain in a Medicinal Cannabis Cohort. J. Headache Pain 2018, 19, 37.

(11) La Porta, C.; Bura, S. A.; Llorente-Onaindia, J.; Pastor, A.; Navarrete, F.; García-Gutiérrez, M. S.; De la Torre, R.; Manzanares, J.; Monfort, J.; Maldonado, R. Role of the Endocannabinoid System in the Emotional Manifestations of Osteoarthritis Pain. Pain 2015, 156, 2001-2012.

(12) Maldonado, R.; Baños, J. E.; Cabañero, D. The Endocannabinoid System and Neuropathic Pain. Pain 2016, 157, S23-S32.

(13) Donovan, K. A.; Oberoi-Jassal, R.; Chang, Y. D.; Rajasekhara, S.; Haas, M. F.; Randich, A. L.; Portman, D. G. Cannabis Use in Young Adult Cancer Patients. J. Adolesc. Young Adult Oncol. 2020, 9, $30-35$.

(14) Maldonado, R.; Berrendero, F.; Ozaita, A.; Robledo, P. Neurochemical Basis of Cannabis Addiction. Neuroscience 2011, $181,1-17$.

(15) Moreira, F. A.; Lutz, B. The Endocannabinoid System: Emotion, Learning and Addiction. Addict. Biol. 2008, 13, 196-212.

(16) Castellano, C.; Rossi-Arnaud, C.; Cestari, V.; Costanzi, M. Cannabinoids and Memory; Animal Studies. Curr. Drug Targets: CNS Neurol. Disord. 2003, 2, 389-402.

(17) Puighermanal, E.; Busquets-Garcia, A.; Maldonado, R.; Ozaita, A. Cellular and Intracellular Mechanisms Involved in the Cognitive Impairment of Cannabinoids. Philos. Trans. R. Soc., B 2012, 367, 3254-3263.

(18) Viñals, X.; Moreno, E.; Lanfumey, L.; Cordomí, A.; Pastor, A.; de La Torre, R.; Gasperini, P.; Navarro, G.; Howell, L. A.; Pardo, L.; Lluís, C.; Canela, E. I.; McCormick, P. J.; Maldonado, R.; Robledo, P. Cognitive Impairment Induced by Delta9-Tetrahydrocannabinol Occurs through Heteromers between Cannabinoid CB1 and Serotonin 5-HT2A Receptors. PLoS Biol. 2015, 13, No. e1002194.

(19) Ferré, S.; Casadó, V.; Devi, L. A.; Filizola, M.; Jockers, R.; Lohse, M. J.; Milligan, G.; Pin, J.-P.; Guitart, X. G Protein-Coupled Receptor Oligomerization Revisited: Functional and Pharmacological Perspectives. Pharmacol. Rev. 2014, 66, 413-434.

(20) Schwarze, S. R.; Ho, A.; Vocero-Akbani, A.; Dowdy, S. F. In Vivo Protein Transduction: Delivery of a Biologically Active Protein into the Mouse. Science 1999, 285, 1569-1572.

(21) Manglik, A.; Kruse, A. C.; Kobilka, T. S.; Thian, F. S.; Mathiesen, J. M.; Sunahara, R. K.; Pardo, L.; Weis, W. I.; Kobilka, B. K.; Granier, S. Crystal Structure of the M-Opioid Receptor Bound to a Morphinan Antagonist. Nature 2012, 485, 321-326.

(22) Ferré, S.; Ciruela, F.; Casadó, V.; Pardo, L. Oligomerization of $\mathrm{G}$ protein-coupled receptors: Still doubted?. In Oligomerization in Health and Disease: From Enzymes to G Protein-Coupled Receptors; Giraldo, J., Ciruela, F., Eds.; Academic Press, 2020; Vol. 169, pp 297321.

(23) Guinart, D.; Moreno, E.; Galindo, L.; Cuenca-Royo, A.; Barrera-Conde, M.; Pérez, E. J.; Fernández-Avilés, C.; Correll, C. U.; Canela, E. I.; Casadó, V.; Cordomi, A.; Pardo, L.; de la Torre, R.; Pérez, V.; Robledo, P. Altered Signaling in CB1R-5-HT2AR Heteromers in Olfactory Neuroepithelium Cells of Schizophrenia Patients Is Modulated by Cannabis Use. Schizophr. Bull. 2020, 46, $1547-1557$.

(24) Galindo, L.; Moreno, E.; López-Armenta, F.; Guinart, D.; Cuenca-Royo, A.; Izquierdo-Serra, M.; Xicota, L.; Fernandez, C.; Menoyo, E.; Fernández-Fernández, J. M.; Benítez-King, G.; Canela, E. I.; Casadó, V.; Pérez, V.; de la Torre, R.; Robledo, P. Cannabis Users Show Enhanced Expression of CB1-5HT2A Receptor Heteromers in Olfactory Neuroepithelium Cells. Mol. Neurobiol. 2018, 55, 63476361.
(25) Neves, V.; Aires-da-Silva, F.; Morais, M.; Gano, L.; Ribeiro, E.; Pinto, A.; Aguiar, S.; Gaspar, D.; Fernandes, C.; Correia, J. D. G.; Castanho, M. A. R. B. Novel Peptides Derived from Dengue Virus Capsid Protein Translocate Reversibly the Blood-Brain Barrier through a Receptor-Free Mechanism. ACS Chem. Biol. 2017, 12, $1257-1268$

(26) Jastrzebska, B.; Chen, Y.; Orban, T.; Jin, H.; Hofmann, L.; Palczewski, K. Disruption of Rhodopsin Dimerization with Synthetic Peptides Targeting an Interaction Interface. J. Biol. Chem. 2015, 290, 25728-25744.

(27) Wang, Y. F.; Xu, X.; Fan, X.; Zhang, C.; Wei, Q.; Wang, X.; Guo, W.; Xing, W.; Yu, J.; Yan, J.-L.; Liang, H.-P. A Cell-penetrating Peptide Suppresses Inflammation by Inhibiting NF- $\kappa$ B Signaling. Mol. Ther. 2011, 19, 1849-1857.

(28) Borroto-Escuela, D. O.; Romero-Fernandez, W.; Mudó, G.; Pérez-Alea, M.; Ciruela, F.; Tarakanov, A. O.; Narvaez, M.; Di Liberto, V.; Agnati, L. F.; Belluardo, N.; Fuxe, K. Fibroblast Growth Factor Receptor 1- 5-Hydroxytryptamine 1A Heteroreceptor Complexes and Their Enhancement of Hippocampal Plasticity. Biol. Psychiatry 2012, 71, 84-91.

(29) Najjar, K.; Erazo-Oliveras, A.; Brock, D. J.; Wang, T.-Y.; Pellois, J.-P. An L- to d-Amino Acid Conversion in an Endosomolytic Analog of the Cell-Penetrating Peptide TAT Influences Proteolytic Stability, Endocytic Uptake, and Endosomal Escape. J. Biol. Chem. 2017, 292, $847-861$.

(30) Cavaco, M.; Valle, J.; da Silva, R.; Correia, J. D. G.; Castanho, M. A. R. B.; Andreu, D.; Neves, V. DPepH3, an Improved Peptide Shuttle for Receptor-Independent Transport across the Blood-Brain Barrier. Curr. Pharm. Des. 2020, 26, 1495-1506.

(31) Cavaco, M.; Pérez-Peinado, C.; Valle, J.; Silva, R. D. M.; Correia, J. D. G.; Andreu, D.; Castanho, M. A. R. B.; Neves, V. To What Extent Do Fluorophores Bias the Biological Activity of Peptides? A Practical Approach Using Membrane-Active Peptides as Models. Front. Bioeng. Biotechnol. 2020, 8, 552035.

(32) Merrifield, R. B.; Juvvadi, P.; Andreu, D.; Ubach, J.; Boman, A.; Boman, H. G. Retro and Retroenantio Analogs of Cecropin-Melittin Hybrids. Proc. Natl. Acad. Sci. U.S.A. 1995, 92, 3449-3453.

(33) Guichard, G.; Benkirane, N.; Zeder-Lutz, G.; van Regenmortel, M. H.; Briand, J. P.; Muller, S. Antigenic Mimicry of Natural LPeptides with Retro-Inverso-Peptidomimetics. Proc. Natl. Acad. Sci. U.S.A. 1994, 91, 9765-9769.

(34) Prades, R.; Oller-Salvia, B.; Schwarzmaier, S. M.; Selva, J.; Moros, M.; Balbi, M.; Grazú, V.; de La Fuente, J. M.; Egea, G.; Plesnila, N.; Teixidó, M.; Giralt, E. Applying the Retro-Enantio Approach to Obtain a Peptide Capable of Overcoming the BloodBrain Barrier. Angew. Chem., Int. Ed. 2015, 54, 3967-3972.

(35) Vaissière, A.; Aldrian, G.; Konate, K.; Lindberg, M. F.; Jourdan, C.; Telmar, A.; Seisel, Q.; Fernandez, F.; Viguier, V.; Genevois, C.; Couillaud, F.; Boisguerin, P.; Deshayes, S. A Retro-Inverso CellPenetrating Peptide for SiRNA Delivery. J. Nanobiotechnol. 2017, 15, 34.

(36) Almiñana, N.; Alsina, M. A.; Ortiz, A.; Reig, F. Comparative Physicochemical Study of SIKVAV Peptide and Its Retro and RetroEnantio Analogues. Colloids Surf., A 2004, 249, 19-24.

(37) Howlett, A. C.; Bidaut-Russell, M.; Devane, W. A.; Melvin, L. S.; Johnson, M. R.; Herkenham, M. The Cannabinoid Receptor: Biochemical, Anatomical and Behavioral Characterization. Trends Neurosci. 1990, 13, 420-423.

(38) Pertwee, R. G. Cannabinoid Pharmacology: The First 66 Years. Br. J. Pharmacol. 2006, 147, S163-S171.

(39) Gaoni, Y.; Mechoulam, R. Isolation, Structure, and Partial Synthesis of an Active Constituent of Hashish. J. Am. Chem. Soc. 1964, $86,1646-1647$.

(40) Manzanares, J.; Julian, M.; Carrascosa, A. Role of the Cannabinoid System in Pain Control and Therapeutic Implications for the Management of Acute and Chronic Pain Episodes. Curr. Neuropharmacol. 2006, 4, 239-257. 
(41) Matsuda, L. A.; Lolait, S. J.; Brownstein, M. J.; Young, A. C.; Bonner, T. I. Structure of a Cannabinoid Receptor and Functional Expression of the Cloned CDNA. Nature 1990, 346, 561-564.

(42) Hudson, B. D.; Hébert, T. E.; Kelly, M. E. Physical and Functional Interaction between CB1 Cannabinoid Receptors and Beta2-Adrenoceptors. Br. J. Pharmacol. 2010, 160, 627-642.

(43) Bagher, A. M.; Laprairie, R. B.; Toguri, J. T.; Kelly, M. E. M.; Denovan-Wright, E. M. Bidirectional Allosteric Interactions between Cannabinoid Receptor 1 (CB1) and Dopamine Receptor 2 Long (D2L) Heterotetramers. Eur. J. Pharmacol. 2017, 813, 66-83.

(44) Rios, C.; Gomes, I.; Devi, L. A. $\mu$ Opioid and CB1 Cannabinoid Receptor Interactions: Reciprocal Inhibition of Receptor Signaling and Neuritogenesis. Br. J. Pharmacol. 2006, 148, 387-395.

(45) Flores, A.; Maldonado, R.; Berrendero, F. CannabinoidHypocretin Cross-Talk in the Central Nervous System: What We Know so Far. Front. Neurosci. 2013, 7, 256.

(46) Mackie, K. Cannabinoid Receptor Homo- and Heterodimerization. Life Sci. 2005, 77, 1667-1673.

(47) Navarro, G.; Carriba, P.; Gandí, J.; Ciruela, F.; Casadó, V.; Cortés, A.; Mallol, J.; Canela, E. I.; Lluis, C.; Franco, R.; Gandí, J.; Ciruela, F.; Casadó, V.; Cortés, A.; Mallol, J.; Canela, E. I.; Lluis, C.; Franco, R. Detection of Heteromers Formed by Cannabinoid CB1, Dopamine D2, and Adenosine A2AG-Protein-Coupled Receptors by Combining Bimolecular Fluorescence Complementation and Bioluminescence Energy Transfer. Sci. World J. 2008, 8, 1088-1097.

(48) Köfalvi, A.; Moreno, E.; Cordomí, A.; Cai, N.-S.; FernándezDueñas, V.; Ferreira, S. G.; Guixà-González, R.; Sánchez-Soto, M.; Yano, H.; Casadó-Anguera, V.; Cunha, R. A.; Sebastião, A. M.; Ciruela, F.; Pardo, L.; Casadó, V.; Ferré, S. Control of Glutamate Release by Complexes of Adenosine and Cannabinoid Receptors. BMC Biol. 2020, 18, 9.

(49) Casadó-Anguera, V.; Cortés, A.; Casadó, V.; Moreno, E. Targeting the Receptor-Based Interactome of the Dopamine D1 Receptor: Looking for Heteromer-Selective Drugs. Expert Opin. Drug Discovery 2019, 14, 1297-1312.

(50) Gomes, I.; Ayoub, M. A.; Fujita, W.; Jaeger, W. C.; Pfleger, K. D. G.; Devi, L. A. G Protein-Coupled Receptor Heteromers. Annu. Rev. Pharmacol. Toxicol. 2016, 56, 403-425.

(51) Hauser, A. S.; Attwood, M. M.; Rask-Andersen, M.; Schiöth, H. B.; Gloriam, D. E. Trends in GPCR Drug Discovery: New Agents, Targets and Indications. Nat. Rev. Drug Discovery 2017, 16, 829-842.

(52) Wacker, D.; Stevens, R. C.; Roth, B. L. How Ligands Illuminate GPCR Molecular Pharmacology. Cell 2017, 170, 414-427.

(53) Pérez-Benito, L.; Henry, A.; Matsoukas, M.-T.; Lopez, L.; Pulido, D.; Royo, M.; Cordomí, A.; Tresadern, G.; Pardo, L. The Size Matters? A Computational Tool to Design Bivalent Ligands. Bioinformatics 2018, 34, 3857-3863.

(54) Pulido, D.; Casadó-Anguera, V.; Pérez-Benito, L.; Moreno, E.; Cordomí, A.; López, L.; Cortés, A.; Ferré, S.; Pardo, L.; Casadó, V.; Royo, M. Design of a True Bivalent Ligand with Picomolar Binding Affinity for a G Protein-Coupled Receptor Homodimer. J. Med. Chem. 2018, 61, 9335-9346.

(55) Pérez-Benito, L.; Llinas Del Torrent, C.; Pardo, L.; Tresadern, G. The Computational Modeling of Allosteric Modulation of Metabotropic Glutamate Receptors. Adv. Pharmacol. 2020, 88, 1-33.

(56) Shao, Z.; Yan, W.; Chapman, K.; Ramesh, K.; Ferrell, A. J.; Yin, J.; Wang, X.; Xu, Q.; Rosenbaum, D. M. Structure of an Allosteric Modulator Bound to the CB1 Cannabinoid Receptor. Nat. Chem. Biol. 2019, 15, 1199-1205.

(57) Filizola, M. Increasingly Accurate Dynamic Molecular Models of G-Protein Coupled Receptor Oligomers: Panacea or Pandora's Box for Novel Drug Discovery? Life Sci. 2010, 86, 590-597.

(58) Hua, T.; Vemuri, K.; Pu, M.; Qu, L.; Han, G. W.; Wu, Y.; Zhao, S.; Shui, W.; Li, S.; Korde, A.; Laprairie, R. B.; Stahl, E. L.; Ho, J.-H.; Zvonok, N.; Zhou, H.; Kufareva, I.; Wu, B.; Zhao, Q.; Hanson, M. A.; Bohn, L. M.; Makriyannis, A.; Stevens, R. C.; Liu, Z.-J. Crystal Structure of the Human Cannabinoid Receptor CB1. Cell 2016, 167, 750-762.e14.
(59) Wacker, D.; Wang, C.; Katritch, V.; Han, G. W.; Huang, X.-P.; Vardy, E.; McCorvy, J. D.; Jiang, Y.; Chu, M.; Siu, F. Y.; Liu, W.; Xu, H. E.; Cherezov, V.; Roth, B. L.; Stevens, R. C. Structural Features for Functional Selectivity at Serotonin Receptors. Science 2013, 340, 615-619.

(60) Gallo, M.; Navarro, G.; Franco, R.; Andreu, D. A2A Receptor Homodimer-Disrupting Sequence Efficiently Delivered by a ProteaseResistant, Cyclic CPP Vector. Int. J. Mol. Sci. 2019, 20, 4937.

\section{NOTE ADDED AFTER ASAP PUBLICATION}

This paper was published on the Web on April 23, 2021. Additional corrections were received post ASAP, and the corrected version was reposted on April 23, 2021. 